\title{
Pre-empted Patents, Infringed Patents and Firms' Participation in Markets for Technology
}

\author{
Grimpe, Christoph; Hussinger, Katrin
}

\author{
Document Version \\ Accepted author manuscript \\ Published in: \\ Research Policy \\ DOI: \\ 10.1016/j.respol.2013.12.001 \\ Publication date: \\ 2014 \\ License \\ CC BY-NC-ND
}

Citation for published version (APA):

Grimpe, C., \& Hussinger, K. (2014). Pre-empted Patents, Infringed Patents and Firms' Participation in Markets for Technology. Research Policy, 43(1), 543-554. https://doi.org/10.1016/j.respol.2013.12.001

Link to publication in CBS Research Portal

\section{General rights}

Copyright and moral rights for the publications made accessible in the public portal are retained by the authors and/or other copyright owners and it is a condition of accessing publications that users recognise and abide by the legal requirements associated with these rights.

\section{Take down policy}

If you believe that this document breaches copyright please contact us (research.lib@cbs.dk) providing details, and we will remove access to the work immediately and investigate your claim.

Download date: 26. Apr. 2023

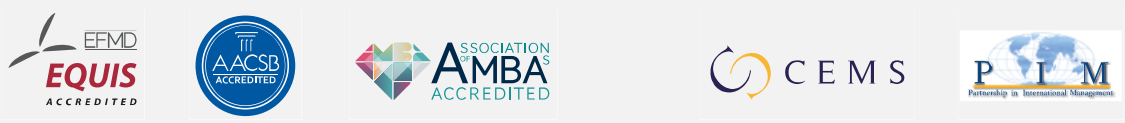




\section{Pre-empted Patents, Infringed Patents and Firms' Participation in Markets for Technology}

\section{Christoph Grimpe and Katrin Hussinger}

Journal article (Post print version)

This article was originally published in Research Policy, Vol. 43, Issue 3, Pages 543५५५. First published online: January 6, २०14

DOI: 10.1016/j.respol.2013.12.001

Uploaded to Research@CBS: March २०16

(2) 2016. This manuscript version is made available under the CC-BY-NC-ND 4.0 license http://creativecommons.org/licenses/by-nc-nd/4.0/ 


\title{
Pre-empted patents, infringed patents and firms’ participation in markets for technology
}

\author{
Christoph Grimpe ${ }^{\mathrm{a}, \mathrm{b}}$ and Katrin Hussinger ${ }^{\mathrm{c}, \mathrm{d}, \mathrm{e}}$ \\ ${ }^{a}$ Copenhagen Business School (Denmark) \\ ${ }^{b}$ Lund University (Sweden) \\ ${ }^{c}$ University of Luxembourg (Luxembourg) \\ ${ }^{d}$ Katholieke Universiteit Leuven, (Belgium) \\ ${ }^{e}$ ZEW Centre for European Economic Research, Mannheim (Germany)
}

Published in Research Policy, Vol. 43, 543-554. The final version can be found at http://www.sciencedirect.com/science/article/pii/S0048733313002205

\begin{abstract}
In recent years, firms have increasingly contributed to and been confronted with a patent landscape characterized by numerous but marginal inventions, overlapping claims and patent fences. As a result, firms risk their patent applications to be pre-empted or to be infringed upon by rivals. While both aspects constitute major challenges for the appropriation of returns to inventive activity, extant literature suggests that participation in the market for technology might actually resolve or at least alleviate these problems. In this paper, we investigate the effect of pre-empted and infringed patents on firms' engagement in in- and cross-licensing. Based on a sample of more than 1100 German manufacturing firms our results show that firms engage in in-licensing as a reaction to pre-empted patents and in cross-licensing if their protected IP was infringed upon. However, these effects vary depending on the fragmentation of technology fields and whether the firm operates in a discrete or complex product industry.
\end{abstract}

Keywords: In-licensing, cross-licensing, pre-emption, infringement

JEL: L24, O34

\section{Corresponding author:}

Christoph Grimpe

Copenhagen Business School

INO, Kilevej 14A, 2000 Frederiksberg, Denmark

Phone: +45-38152530, Fax: +45-38152540, Email: cg.ino@cbs.dk 


\section{Introduction}

Patents have frequently been characterized as the "gold standard” in protecting a firm's intellectual property (IP) (Scotchmer, 2004). They grant the holder the right to exclude third parties from using the protected technology and by that establish a temporary monopoly. As a result, patents allow firms to appropriate the returns from their inventive activities and they provide the incentives to further engage in technology development. In recent years, however, firms using patents with the ambition to protect their inventions have been confronted with two major problems.

On the one hand, firms experience - to an increasing extent - a patent landscape characterized by numerous but marginal inventions (Gallini, 2002), overlapping claims and multiple patent ownerships for complementary technologies (Heller and Eisenberg, 1998; Scotchmer, 2004), as well as by patent fences of substitute technologies owned by a single firm or a group of firms (Cohen et al., 2000; Schneider, 2008). As a result, a firm that wishes to protect an invention may be blocked by rivals' patents (Graff et al., 2003; Grimpe and Hussinger, 2008). Rival patents might have deliberately been written to include broad claims so that they pre-empt another firm's ambition to file for patent protection, i.e. prior art compromises the patentability of claims in the firm's patent application (Guellec et al., 2012). On the other hand, a firm's granted patents may be infringed upon by competitors since many areas of research are so extensively protected by patents that new projects are likely to touch existing patents (Arora and Gambardella, 2010). Both problems suggest that a firm's opportunities to appropriate the returns from its inventions decrease, providing lower incentives to innovate in the first place.

An aggregate response to these two problems has been an increase in the overall filing of patents because a large patent portfolio enhances firms' bargaining power in disputes over IP rights with rivals (Ziedonis, 2004). This may lead to “overfencing” in technology markets (David, 2001), thereby perpetuating the patent thicket (Shapiro, 2001). At the same time, patents also provide the basis of markets for technology (Cockburn et al., 2010). Markets for technology may improve the efficiency in innovation because patents constitute property rights over inventions that can be contracted and exchanged, either by transferring the patent itself or by licensing (Arora et al., 2004). The ability to negotiate licensing contracts should in principle alleviate the two problems described above. First, licenses allow firms to commercialize their inventions and hence to appropriate value because they can license-in the 
required IP. If the firm disposes of valuable IP itself, it might also negotiate a cross-licensing contract. Second, licensing, and particularly cross-licensing, may enable a firm to still appropriate value despite its IP being infringed upon by rivals. Since rivals face the threat of being sued for infringement, the firm might be able to negotiate favorable licensing terms.

While the possibility of licensing has been found to support the functioning of the market for technology (Arora et al., 2004), empirical evidence on a firm's use of licensing as a response to pre-empted and infringed patents is rather scarce. In this paper, we seek to look into a firm's licensing activities, both in the form of in-licensing and cross-licensing, when patent filings by the firm had been pre-empted and technological inventions had been infringed upon. We investigate whether these two major challenges in the appropriation of returns from invention influence the likelihood of in-licensing and cross-licensing, while controlling for firm, industry and technology characteristics.

Our analysis reflects the special characteristics of today's patent landscape that firms are exposed to in two ways. First, we control for the extent to which ownership rights to external technologies are distributed among different firms by including a citation-based measure of fragmentation (Ziedonis, 2004; von Graevenitz et al., 2008). Potential hold-up problems are more likely to occur in fragmented technology areas which might have strong implications for a firm's licensing activities. Second, we distinguish between complex product industries and discrete product industries (Cohen et al., 2000). Industries characterized as complex are associated with products that require a large number of patentable elements while industries characterized as discrete produce products based on relatively few patentable elements. Recent contributions have shown that technology landscapes in complex product industries are characterized by high fragmentation (Ziedonis, 2004). As a result, the transaction costs associated with licensing activities increase due to a large number of assignees. Differentiating between complex and discrete product industries in this context is important because the writing of contracts about technologies is easier and less costly in discrete product industries, on the one hand. On the other hand, hold-up is more likely in complex product industries so that licensing is expected to be more important to mitigate such hold-up problems. The overall effect on firms' licensing activities thus remains an empirical question.

Analytically, we will derive two hypotheses regarding the effect of pre-empted patents and infringed patents on in-licensing and cross-licensing. The contribution of this paper is thus threefold: First, we analyze the effects of a firm's technologies being blocked or infringed upon on licensing activities. We focus on both in- and cross-licensing of technologies which 
extends prior studies that exclusively focus on in-licensing (e.g., Cockburn et al., 2010; Siebert and von Graevenitz, 2010) or cross-licensing (Galasso, 2012). Moreover, our research complements and extends the very few studies that look into the extent of patent infringement and its consequences (Weatherall et al., 2009; Galasso, 2012). Second, our analysis reflects the characteristics of the patent landscape that firms experience by accounting for fragmentation and complex versus discrete product industries (Cohen et al., 2000; Ziedonis, 2004). Our research thus provides a more nuanced understanding of the effects of pre-empted and infringed patents on both in- and cross-licensing with an eye on the conditions under which those effects are likely to emerge. Third, our analysis rests on a comprehensive sample of 1162 manufacturing firms in Germany that experienced pre-emption and infringement of patents on their technologies. The sample combines survey and patent data from the European Patent Office (EPO) which, contrary to the U.S. Patent and Trademark Office, allows for a precise identification to what extent patent applications filed by a firm are being blocked by prior art.

The remainder of this paper is organized as follows. Section 2 provides the literature background and details our theoretical framework. Section 3 shows our empirical methods while the results are presented in section 4 . We discuss key findings as well as limitations and future research avenues in section 5.

\section{Theoretical framework}

\subsection{Literature background}

Despite the prominence of patents as instruments to appropriate the returns from inventive activity, there is ample evidence for the U.S. and Europe that the protection of IP is often not the most attractive feature of patents (Arundel et al., 1995; Cohen et al., 2000; Encaoua et al., 2006; Amara et al., 2008). The value of patents is rather determined by their importance as bargaining chips in the market for technology, e.g. in licensing or M\&A negotiations, and by their potential to block the inventions of competitors (Graff et al., 2003; Grimpe and Hussinger, 2008). Although patents facilitate bargaining in technology markets, they are difficult to value, their boundaries are often blurry and difficult to define, and parties owning related, previously patented technologies are often unknown in advance (Merges and Nelson, 1990). This is, for one, because the patent system in practice works like a "signpost" system in which the patent specification is rather indicative of the patented idea (e.g. Meurer, 1989; Waterson, 1990) rather than providing an exact coverage of the patented idea like in a 
"fencepost" system where there is no role for courts to judge over questions of interpretation (e.g. Horstmann et al., 1985). Moreover, this is the result of enhanced incentives to patent strategically (Levin et al., 1987; Arundel et al., 1995; Duguet and Kabla, 1998; Cohen et al., 2000; Blind et al., 2006) in the presence of fragmented technology landscapes, patent thickets and patent fences (Ziedonis, 2004) and of increased attempts to build up own patent portfolios explicitly for a better bargaining position in licensing negotiations and disputes over IP rights (Reitzig, 2004; Blind et al., 2009). In consequence, fragmentation accelerates and multiple ownership, overlapping claims, patent thickets and patent fences occur more frequently, leaving patenting firms in an increasingly opaque and uncertain environment (Ziedonis, 2004). Ziedonis (2004) finds that firms which are confronted with fragmented property rights required to commercialize an innovation will patent more aggressively to reduce the uncertainty of being litigated or to threaten competitors with a reciprocal suit. In fact, the surge in patent applications worldwide over the past two decades has been accompanied by an increase in the number of legal disputes over patent rights (Lanjouw and Schankerman, 1997). As a consequence, using patents as instruments to protect a firm's IP has actually become more complicated. On the one hand, a firm's patent applications are being blocked by rivals' patents or patent applications. On the other hand, patents are being infringed upon as a result of rivals’ new technology development. Both aspects constitute major problems in a firm's efforts to appropriate the returns from invention.

Several recent contributions have dealt with patent blocking. In general, existing patents can block successive patent applications by threatening their novelty requirements (Scotchmer, 1991; Shapiro, 2001; Jaffe and Lerner, 2004; Ziedonis, 2004; Grimpe and Hussinger, 2008). However, even though an invention may involve an inventive step, rival patents might have deliberately been written to include broad claims so that they pre-empt the firm's ambition to file for patent protection (Guellec et al., 2012). Guellec et al. (2012) find that those patent applications that are later withdrawn have the strongest pre-emptive power. A recent survey of German firms shows that more than 40 percent of patenting firms apply for patents in order to block or pre-empt competitors (Blind et al., 2009). Blind et al. (2009) find particularly striking evidence of "defensive blocking” through patenting. They define this as a forward-looking protection strategy directed at protecting the firm's position in technology markets. In this regard, pre-emptive patents can be used to hinder competitors from developing a competing alternative technology or to remove existing patent fences. In fact, von Graevenitz et al. (2008) find for the U.S. semiconductor industry that a firm's patenting 
activity increases with the density of patent thickets threatening to block its patent applications.

Few contributions have to date dealt with patent infringement (Weatherall et al., 2009). Based on a survey in Australia, Weatherall and Webster (2009) report that 31 percent of all patents owned by SMEs were infringed upon. Another study on European SMEs reports even twice that rate (Kingston, 2004). Infringement may however also be unintentional. Since many areas of research are so extensively protected by patents, new projects are likely to touch existing patents without knowing (Arora and Gambardella, 2010). If the firm had made large sunk investments into a particular technology, it may end up in a hold-up situation. Galasso (2012) analyzes a small sample of firms in the semiconductor industry that were “interacting”, i.e. they were either in a patent dispute or entered a broad cross-licensing agreement or both. He finds that high capital intensity increases the probability of signing a broad cross-licensing agreement and lowers the length of licensing negotiations. Moreover, firms that patent in similar technology areas and whose patent portfolios are complementary are found to have a higher probability of cross-licensing since these two factors increase the likelihood of future infringement.

Prior literature has suggested that licensing and hence participation in the market for technology provides a way to cope with problems resulting from pre-emption and infringement in fragmented fields of technology (Arora et al., 1999). However, several problems are associated with trading IP rights at arm's length (Heller and Eisenberg, 1998; Somaya and Teece, 2000; Graff et al., 2003). First, fragmented technology markets and blurry boundaries of IP rights lead to diffuse entitlement problems (Heller and Eisenberg, 1998). Second, the difficulty of valuing IP rights leads to value allocation problems between the technology owner and the licensee (Graff et al., 2003). Third, the dynamic and uncertain environment of technology markets causes difficulties when setting up and enforcing the contract due to monitoring and metering problems (Ziedonis, 2004). Lastly, strategic problems may arise if IP rights are traded at arm's length. For example, rent-dissipation effects can result when technologies are licensed out to other firms, because the licensees may become new competitors in product markets (Graff et al., 2003). ${ }^{1}$ All the problems associated with arm's-length contracts lead to higher transaction costs which reduce the

\footnotetext{
${ }^{1}$ It should be noted that there are also strategic reasons for firms to license technologies to competitors since out-licensing for instance increases their costs and grants the patent holder a cost advantage (e.g., Shapiro, 1985; Wang, 1998).
} 
propensity to engage in licensing. Moreover, since higher fragmentation of technology markets is associated with higher licensing expenditure of the firm (Cockburn et al., 2010), lower funds are available for own technology development.

Licensing and the participation in the market for technology may also be complicated by the characteristics of industries and the product markets these industries serve. Product industries characterized as complex exhibit a large number of patentable elements per product while product industries characterized as discrete contain relatively few patentable elements per product. Hence, the number of patents available in a technology area is determined by the existence of these technological opportunities and their facets (Cohen et al., 2000; von Graevenitz et al., 2008). Complexity arises when several facets within technological opportunities can be patented. A higher number of patentable facets increases the potential number of firms owning patents that refer to the same technological opportunity. Firms therefore tend to pile up a stack of patents to counter the threat of hold-up. In contrast to complex product industries, discrete product industries refer only to one facet of the technological opportunity that is needed for the creation of a product. The value of each patent will thus be independent from other firms' patents. This implies that, for discrete product industries, there are relatively clear standards to evaluate the patent's validity and protect it against infringement. Complex product industries, on the contrary, are characterized by a less transparent link between patenting and value appropriation as it is unclear whether it will be feasible to defend the IP rights because of interdependent technologies (Levin et al., 1987; Cohen et al., 2000).

\subsection{Hypotheses}

The above arguments suggest that licensing may in principle mitigate the problems associated with pre-empted and infringed patents. However, empirical evidence of the effects on both in-licensing and cross-licensing is scarce. The fact that patent applications of a firm had been blocked by rivals suggests that the applications were not strong in the light of existing prior art. As a consequence, we expect that licenses allow firms to commercialize their inventions and hence to appropriate value, even though their patent applications had been compromised by rival patents, i.e. they may license-in the required IP (Cockburn et al., 2010). Hence, our first hypothesis reads:

Hypothesis 1 (H1): The higher the share of patent applications being pre-empted by rivals, the higher the likelihood will be to engage in in-licensing. 
Second, in case a firm's IP is infringed upon by rivals, licensing, and particularly crosslicensing, may enable a firm to appropriate value (Shapiro, 2001). The firm might be able to negotiate favorable cross-licensing terms because rivals face the threat of being sued for infringement. It has to be noted, though, that we can only expect such effects on licensing in case the firm's IP is actually protected through patents. As a result, our second hypothesis reads as follows:

Hypothesis 2 (H2): Firms whose IP was infringed upon by rivals have a higher likelihood to engage in cross-licensing.

A firm's decision to engage in licensing may, however, change depending on the characteristics of the technology. Since higher fragmentation of technology markets is associated with higher licensing expenditure, firms might refrain from in-licensing the required IP. Moreover, differentiating between complex and discrete product industries is important because of two diverging effects. On the one hand, writing licensing contracts should be easier, less costly and hence more likely in discrete product industries. On the other hand, licensing might be more important in complex product industries where innovative products are typically based on several patent-protected technologies. Firms operating in complex product industries may also more likely engage in cross-licensing if firms' technology development is mutually interdependent, as for example in the information and communications technology (ICT) industry. The overall effects of pre-empted and infringed patents on in- and cross-licensing thus remain an empirical question.

\section{Empirical methods}

\subsection{Data}

We test our research questions using data from the Mannheim Innovation Panel (MIP), a survey which has been conducted annually by the Centre for European Economic Research (ZEW) on behalf of the German Federal Ministry of Education and Research (BMBF) since 1992. The MIP is the German part of the Community Innovation Survey (CIS) of the European Commission. In 2008, firms were asked about their in- and cross-licensing activities during the period from 2005 to 2007. This year constitutes a cross-sectional database for our empirical analysis. The firm information was linked to the firms' patent records at the European Patent Office (EPO). Based on firm names and addresses the respondents of the survey were linked to corresponding patent applicants. The link was 
supported by a computerized text field based search algorithm and every firm-patent applicant match proposed by the program was manually checked.

We restrict the sample to manufacturing firms as patents and hence licensing is likely of a different nature in service industries. Further, only firms that applied for at least one patent at the EPO are taken into account. The latter restriction is necessary because patent blocking and infringement are irrelevant for non-patenting firms. This leaves us with a sample of 1162 firms in the manufacturing sector that applied for at least one patent at the EPO.

\subsection{Measures}

\section{Dependent variables}

In the survey, firms were asked whether they in-licensed and whether they cross-licensed technology during the period from 2005 to 2007. Since no information on the actual amount spent is available, our dependent variables are two dummy variables that take the value of one (and zero otherwise) if respectively in-licensing or cross-licensing had occurred.

\section{Explanatory variables}

Our first main explanatory variable is the number of a firm's pre-empted patent applications divided by the total number of the firm's patent applications. The measure is based on detailed information from the patent application procedure at the EPO (Guellec et al., 2012). Each EPO patent application is evaluated by a patent examiner who scrutinizes whether a patent can be granted. The result of this examination is summarized in the so-called "search report”. An important information given in the search report is a list of all documents which are considered as relevant prior art for the patent application in question. Based on the review of prior art a decision is made as to whether a technology is novel enough to get granted patent protection. An interesting feature of the EPO search reports is that references to prior art are classified according to their importance for the patent application in question. Prior art which threatens the novelty requirement of the patent application can thus be distinguished from previous inventions that belong to the state of the art in a particular technology field but do not challenge the novelty of the patent application. References to prior art are marked with an " $\mathrm{X}$ " if the invention cannot be considered to be novel or cannot be considered to involve an inventive step when the referenced document alone is taken into consideration. References are marked with a "Y" if the invention cannot be considered to involve an inventive step when the referenced document is combined with one or more other documents of the same category, such a combination being obvious to a person skilled in the art (Harhoff et al., 
2005). If a patent has many references classified with $X$ or $Y$ it can still be granted (although this is less likely). This can be the case for patent applications with many claims. $\mathrm{X}$ and $\mathrm{Y}$ references may only pertain to some claims and the remaining claims can be strong enough to get a (modified) application granted. The information on patent references is taken from the EPO/OECD patent citation database. An earlier version of this database is fully described and analyzed in Webb et al. (2005).

We use the information on prior art in the search report to construct a measure for pre-empted patents. We build on the fact that a patent application with many $\mathrm{X}$ and $\mathrm{Y}$ references can be considered a weak patent application with a high likelihood of not being granted. Guellec et al. (2012) provide empirical evidence for the significance of patent citation categories for the identification of pre-emptive patents. They find that such blocking references increase the likelihood of patents not being granted or being withdrawn. We exploit this correlation to construct the measure for pre-empted patents, i.e. we use the share of patent applications that received at least one blocking reference (X or Y) in the period from 2000 to 2004. The period from 2000 to 2004 is chosen because the survey information refers to the period from 2005 to 2007 and we seek to measure the reaction of firms to pre-empted patents in terms of their licensing activities.

The second main explanatory variable is infringement. In the survey, firms were asked to indicate whether or not technological inventions had been infringed upon by other firms during the period from 2005 to 2007. The question includes a follow-up question that asks whether the IP infringed was actually protected by a patent. Our regressions use both indicator variables alternatively in order to investigate whether infringement is generally associated with licensing or only when infringement refers to a patent.

Fragmentation is measured following the method originally proposed by Ziedonis (2004). It is based on the concentration of cited IP ownership patents as measured by backward citations in patents. We follow von Graevenitz et al. (2012) who calculated this measure for the 30 different Fraunhofer technology classes for patents at the EPO. Other than focusing on all patent citations to third parties as done by Ziedonis (2004) for U.S. patents, von Graevenitz et al. (2012) only focus on $\mathrm{X}$ and $\mathrm{Y}$ citations because these are the critical backward citations. Such information is not available for the U.S. ${ }^{2}$ Since the fragmentation index is available to us as an aggregated measure for the 30 different Fraunhofer technology

\footnotetext{
${ }^{2}$ We thank Georg von Graevenitz for providing us with data on fragmentation.
} 
classes we transformed it into a firm level measure by weighting the fragmentation index with the firms' patent activities across the 30 technology classes in the period from 2000 to 2004. We use the fragmentation index from 2003 because this is the latest year available to us. In any case, the measure is rather stable over the years. Our final measure captures the extent to which each individual firm faces fragmentation in its fields of technological activity.

The fragmentation measure has been suggested to be higher in complex than in discrete product industries (von Graevenitz et al., 2012). In order to consider the specific characteristics of product industries in contrast to fields of technology, we use the distinction between complex and discrete product industries. The definition of complex and discrete product industries follows Cohen et al. (2000). Discrete product industries include chemicals, food, paper, and metals, and the group of complex product industries consists of machinery and equipment, electronics, and transportation equipment, i.e. NACE 15-28 and NACE 2935, respectively. All other manufacturing sectors are defined as complex product industries.

\section{Control variables}

We control for several firm characteristics that might influence a firm's engagement in licensing. We include measures of the firm's R\&D intensity ( $R \& D$ expenditure divided by the number of employees) and patent intensity (patent stock divided by the number of employees) to control for the technology orientation of the firm. Particularly the patent intensity should be positively correlated with licensing since patent rights are tradable on markets for technology. The patent stock is calculated using the perpetual inventory method on all the firm's patent applications at the EPO with a knowledge depreciation rate of 0.15 as is standard in the literature (e.g., Hall, 1990). Moreover, we control for a firm's collaboration activities in technology development with various types of partners. Collaboration reflects a firm's open innovation strategy that may also influence licensing activity (e.g., Laursen and Salter, 2006; Grimpe and Kaiser, 2010). We therefore include six dummy variables indicating whether the firm had collaborated with customers (other firms or private consumers), suppliers (materials or services), competitors, or universities and research institutes. Further, we include a dummy variable indicating whether a firm is an exporter, and whether it is part of a group of firms. Firm size is measured as the number of employees (in log). We also include a regional control variable indicating whether a firm is located in East Germany, a region within Germany that is still economically lacking behind the West. Finally, industry affiliation is controlled for by including a set of industry dummies based on the NACE 2-digit classification system. 


\subsection{Model}

We estimate probit and bivariate probit models for a firm's decision to engage in in-licensing and in cross-licensing using different model specifications. We first test for the direct effect of pre-empted and infringed patents on licensing, while controlling for fragmentation of technologies, before we include interaction terms between fragmentation and pre-empted and infringed patents, respectively. The idea is to test whether the effect of pre-empted patents and infringed patents changes depending on the level of fragmentation. Finally, we conduct a split-sample analysis for the effects of pre-empted and infringed patents in discrete versus complex product industries.

\section{$4 \quad$ Results}

\subsection{Descriptive statistics}

Table 1 shows descriptive statistics for our sample of patenting firms in German manufacturing. The first column presents means and standard deviations for the variables of interest for the full sample; the second and third columns distinguish between discrete and complex product industries. 
Table 1: Descriptive statistics

\begin{tabular}{|c|c|c|c|c|c|c|}
\hline & \multicolumn{2}{|c|}{ Full sample } & \multicolumn{2}{|c|}{$\begin{array}{c}\text { Discrete industries } \\
\text { NACE 15-28; 36-37 }\end{array}$} & \multicolumn{2}{|c|}{$\begin{array}{c}\text { Complex industries } \\
\text { NACE 29-35 }\end{array}$} \\
\hline & mean & st.d. & mean & st.d. & mean & st.d. \\
\hline In-licensing & 0.25 & 0.43 & 0.24 & 0.43 & 0.25 & 0.44 \\
\hline Cross-licensing & 0.07 & 0.25 & 0.06 & 0.23 & 0.08 & 0.28 \\
\hline Log(emplyment) & 4.71 & 1.72 & 4.66 & 1.68 & 4.76 & 1.76 \\
\hline R\&D/ employment & 0.01 & 0.02 & 0.01 & 0.02 & 0.01 & 0.02 \\
\hline Patentstock/ employment & 0.01 & 0.06 & 0.01 & 0.07 & 0.02 & 0.04 \\
\hline Pre-empted patents & 0.18 & 0.35 & 0.15 & 0.32 & 0.22 & 0.36 \\
\hline Infringement & 0.24 & 0.43 & 0.16 & 0.36 & 0.32 & 0.47 \\
\hline Infringement (not protected) & 0.08 & 0.28 & 0.06 & 0.23 & 0.11 & 0.31 \\
\hline Infringement (protected) & 0.15 & 0.35 & 0.10 & 0.30 & 0.19 & 0.39 \\
\hline Fragmentation index & 0.01 & 0.03 & 0.01 & 0.02 & 0.02 & 0.03 \\
\hline Export dummy & 0.88 & 0.33 & 0.86 & 0.34 & 0.89 & 0.31 \\
\hline Part of a group & 0.49 & 0.50 & 0.49 & 0.50 & 0.48 & 0.50 \\
\hline Collaboration B2B & 0.84 & 0.37 & 0.84 & 0.37 & 0.83 & 0.37 \\
\hline Collaboration B2C & 0.27 & 0.45 & 0.33 & 0.47 & 0.22 & 0.41 \\
\hline Collaboration w/ mat. suppliers & 0.60 & 0.49 & 0.65 & 0.48 & 0.56 & 0.50 \\
\hline Collaboration w/ serv. suppliers & 0.38 & 0.49 & 0.38 & 0.49 & 0.38 & 0.49 \\
\hline Collaboration w/ competitors & 0.22 & 0.41 & 0.23 & 0.42 & 0.21 & 0.41 \\
\hline Collaboration w/ universities & 0.54 & 0.50 & 0.49 & 0.50 & 0.60 & 0.49 \\
\hline East Germany & 0.29 & 0.45 & 0.29 & 0.45 & 0.29 & 0.45 \\
\hline Food, tobacco, textile, leather & 0.08 & 0.28 & 0.17 & 0.38 & 0.00 & 0.00 \\
\hline Wood, pulp, coke, chemicals & 0.17 & 0.38 & 0.36 & 0.48 & 0.00 & 0.00 \\
\hline Rubber, plastics & 0.05 & 0.22 & 0.11 & 0.31 & 0.00 & 0.00 \\
\hline Non-metallic minerals & 0.05 & 0.21 & 0.09 & 0.29 & 0.00 & 0.00 \\
\hline Basic metals & 0.05 & 0.21 & 0.09 & 0.29 & 0.00 & 0.00 \\
\hline Fabricated metals & 0.09 & 0.28 & 0.17 & 0.38 & 0.00 & 0.00 \\
\hline Machinery & 0.16 & 0.37 & 0.00 & 0.00 & 0.31 & 0.46 \\
\hline Office machinery & 0.02 & 0.13 & 0.00 & 0.00 & 0.03 & 0.18 \\
\hline Electrical machinery & 0.07 & 0.26 & 0.00 & 0.00 & 0.15 & 0.35 \\
\hline Radio, tv, communication & 0.04 & 0.20 & 0.00 & 0.00 & 0.08 & 0.27 \\
\hline Medical instruments & 0.12 & 0.33 & 0.00 & 0.00 & 0.24 & 0.43 \\
\hline Motor vehicles & 0.10 & 0.30 & 0.00 & 0.00 & 0.19 & 0.39 \\
\hline Number of observations & \multicolumn{2}{|c|}{1162} & \multicolumn{2}{|c|}{570} & \multicolumn{2}{|c|}{592} \\
\hline
\end{tabular}

The descriptive statistics reveal some interesting insights. First of all, they show that 25 percent of the firms acquire patent licenses from third parties but only 7 percent engage in cross-licensing. The percentages do not vary significantly for complex and discrete product industries, although the share of firms engaged in cross-licensing is marginally higher in complex product industries. Regarding pre-empted patents, it turns out that on average 18 percent of a firm's patent applications received a blocking citation. Moreover, 24 percent of the firms report some form of infringement of their technological inventions. The largest share refers to infringement of patent-protected technologies. It turns out that both preempted and infringed patents occur much more often in complex than discrete product industries. Table 1 further shows for most control variables that there is on average no 
significant difference between firms in complex and discrete product industries, e.g. in terms of labor force, R\&D intensity or their patent stock per employee. To further explore the relationships between the variables used in the empirical analysis, Table 4 in the appendix reports the bivariate correlations.

\subsection{Multivariate results}

In order to analyze the effect of pre-empted and infringed patents on the likelihood to be involved in in-licensing and cross-licensing we run a series of probability models. Table 2 shows the results. Models 1 and 2 include all control variables and the fragmentation index. Interestingly, we do not find a significant effect of fragmentation on in- and cross-licensing. This finding contrasts with results found by Cockburn et al. (2010) who report a positive relationship between fragmentation and a firm's expenditures for in-licensing. However, their result does not hold if they restrict their sample to positive observations on licensing expenditure as a share of sales. These inconsistent findings indicate that licensing might primarily be driven by other factors such as pre-empted and infringed patents.

Models 3 and 4 include our measure of pre-empted patents and subsequently the measure of infringement. We find that pre-empted patents are a significant determinant of in-licensing, which lends support to hypothesis 1 . Moreover, we find that infringement is positively associated with cross-licensing, providing support for hypothesis 2. Models 7 and 8 split up the infringement variable into infringement of legally protected and unprotected IP. It turns out that only infringement of protected technology increases the likelihood of cross-licensing. Models 5 to 8 each contain both main explanatory variables to control whether the hypothesized effect holds in the presence of the other main effect. Models 3 to 8 in Table 5 in the appendix report the marginal effects which also provide support for our hypotheses.

We also estimate bivariate probit models that include the same variables as presented above. Table 7 in the appendix shows the results. It turns out that the empirical specification is very robust against ignoring the possibility of correlated error terms of the in- and cross-licensing equation when compared to the estimated coefficients of the probit models. The correlation coefficients of the error terms turn out to be highly significant in all models and range between 0.41 and 0.45 . This finding indicates a positive correlation in the unobserved determinants of in- and cross-licensing activities which suggests they may be considered as complementary activities. 
Overall, these findings show, first, that pre-empted patents are in fact an important motivation for firms to license-in technology in order to be able to commercialize inventions and to appropriate the returns. Second, the results for infringement show that firms are able to engage in cross-licensing and still appropriate value despite being infringed upon. 
Table 2: Probit models for in- and cross-licensing

\begin{tabular}{|c|c|c|c|c|c|c|c|c|}
\hline & 1 & 2 & 3 & 4 & 5 & 6 & 7 & 8 \\
\hline & $\begin{array}{c}\text { In- } \\
\text { licensing }\end{array}$ & $\begin{array}{c}\text { Cross- } \\
\text { licensing }\end{array}$ & $\begin{array}{c}\text { In- } \\
\text { licensing }\end{array}$ & $\begin{array}{c}\text { Cross- } \\
\text { licensing }\end{array}$ & $\begin{array}{c}\text { In- } \\
\text { licensing }\end{array}$ & $\begin{array}{c}\text { Cross- } \\
\text { licensing }\end{array}$ & $\begin{array}{c}\text { In- } \\
\text { licensing }\end{array}$ & $\begin{array}{c}\text { Cross- } \\
\text { licensing }\end{array}$ \\
\hline Log(employment) & $\begin{array}{c}0.20 * * * \\
(0.03)\end{array}$ & $\begin{array}{c}0.35 * * * \\
(0.05)\end{array}$ & $\begin{array}{c}0.17 * * * \\
(0.03)\end{array}$ & $\begin{array}{c}0.31 * * * \\
(0.05)\end{array}$ & $\begin{array}{c}0.16 * * * \\
(0.03)\end{array}$ & $\begin{array}{c}0.31 * * * \\
(0.05)\end{array}$ & $\begin{array}{c}0.15^{* * *} \\
(0.03)\end{array}$ & $\begin{array}{c}0.30 * * * \\
(0.05)\end{array}$ \\
\hline R\&D/ employment & $\begin{array}{c}8.45^{* * *} \\
(2.36)\end{array}$ & $\begin{array}{l}6.20 * * \\
(2.60)\end{array}$ & $\begin{array}{c}8.61 * * * \\
(2.40)\end{array}$ & $\begin{array}{c}6.83 * * \\
(2.68)\end{array}$ & $\begin{array}{c}8.53 * * * \\
(2.39)\end{array}$ & $\begin{array}{c}6.87 * * \\
(2.69)\end{array}$ & $\begin{array}{c}8.36 * * * \\
(2.38)\end{array}$ & $\begin{array}{c}6.56 * * \\
(2.67)\end{array}$ \\
\hline Patentstock/ employment & $\begin{array}{c}0.55 \\
(0.70)\end{array}$ & $\begin{array}{c}2.47 * * * \\
(0.79)\end{array}$ & $\begin{array}{c}0.11 \\
(0.72)\end{array}$ & $\begin{array}{c}2.60 * * * \\
(0.80)\end{array}$ & $\begin{array}{c}0.11 \\
(0.72)\end{array}$ & $\begin{array}{c}2.65^{* * *} \\
(0.82)\end{array}$ & $\begin{array}{c}0.11 \\
(0.73)\end{array}$ & $\begin{array}{c}2.50 * * * \\
(0.82)\end{array}$ \\
\hline Export dummy & $\begin{array}{l}-0.12 \\
(0.14)\end{array}$ & $\begin{array}{c}0.10 \\
(0.24)\end{array}$ & $\begin{array}{l}-0.13 \\
(0.14)\end{array}$ & $\begin{array}{c}0.07 \\
(0.26)\end{array}$ & $\begin{array}{l}-0.16 \\
(0.14)\end{array}$ & $\begin{array}{c}0.08 \\
(0.26)\end{array}$ & $\begin{array}{l}-0.16 \\
(0.14)\end{array}$ & $\begin{array}{c}0.05 \\
(0.25)\end{array}$ \\
\hline Part of a group & $\begin{array}{c}0.14 \\
(0.10)\end{array}$ & $\begin{array}{c}0.10 \\
(0.16)\end{array}$ & $\begin{array}{c}0.14 \\
(0.10)\end{array}$ & $\begin{array}{c}0.09 \\
(0.17)\end{array}$ & $\begin{array}{c}0.14 \\
(0.10)\end{array}$ & $\begin{array}{c}0.10 \\
(0.17)\end{array}$ & $\begin{array}{c}0.15 \\
(0.10)\end{array}$ & $\begin{array}{c}0.11 \\
(0.17)\end{array}$ \\
\hline Collaboration B2B & $\begin{array}{c}0.14 \\
(0.13)\end{array}$ & $\begin{array}{c}0.15 \\
(0.21)\end{array}$ & $\begin{array}{c}0.12 \\
(0.13)\end{array}$ & $\begin{array}{c}0.05 \\
(0.22)\end{array}$ & $\begin{array}{c}0.11 \\
(0.13)\end{array}$ & $\begin{array}{c}0.05 \\
(0.22)\end{array}$ & $\begin{array}{c}0.12 \\
(0.13)\end{array}$ & $\begin{array}{c}0.08 \\
(0.22)\end{array}$ \\
\hline Collaboration B2C & $\begin{array}{c}0.40 * * * \\
(0.10)\end{array}$ & $\begin{array}{c}0.02 \\
(0.16)\end{array}$ & $\begin{array}{c}0.40 * * * \\
(0.10)\end{array}$ & $\begin{array}{c}0.05 \\
(0.16)\end{array}$ & $\begin{array}{c}0.38 * * * \\
(0.10)\end{array}$ & $\begin{array}{c}0.06 \\
(0.16)\end{array}$ & $\begin{array}{c}0.37 * * * \\
(0.10)\end{array}$ & $\begin{array}{c}0.01 \\
(0.16)\end{array}$ \\
\hline $\begin{array}{l}\text { Collaboration with } \\
\text { material suppliers }\end{array}$ & $\begin{array}{c}0.06 \\
(0.09)\end{array}$ & $\begin{array}{c}0.16 \\
(0.16)\end{array}$ & $\begin{array}{c}0.06 \\
(0.10)\end{array}$ & $\begin{array}{c}0.16 \\
(0.17)\end{array}$ & $\begin{array}{c}0.07 \\
(0.10)\end{array}$ & $\begin{array}{c}0.16 \\
(0.17)\end{array}$ & $\begin{array}{c}0.06 \\
(0.10)\end{array}$ & $\begin{array}{c}0.18 \\
(0.17)\end{array}$ \\
\hline $\begin{array}{l}\text { Collaboration with } \\
\text { service suppliers }\end{array}$ & $\begin{array}{c}0.03 \\
(0.09)\end{array}$ & $\begin{array}{c}0.21 \\
(0.14)\end{array}$ & $\begin{array}{c}0.02 \\
(0.09)\end{array}$ & $\begin{array}{c}0.18 \\
(0.15)\end{array}$ & $\begin{array}{c}0.01 \\
(0.09)\end{array}$ & $\begin{array}{c}0.19 \\
(0.15)\end{array}$ & $\begin{array}{c}0.01 \\
(0.09)\end{array}$ & $\begin{array}{c}0.17 \\
(0.14)\end{array}$ \\
\hline $\begin{array}{l}\text { Collaboration with } \\
\text { competitors }\end{array}$ & $\begin{array}{c}0.07 \\
(0.10)\end{array}$ & $\begin{array}{c}0.21 \\
(0.16)\end{array}$ & $\begin{array}{c}0.07 \\
(0.10)\end{array}$ & $\begin{array}{c}0.24 \\
(0.16)\end{array}$ & $\begin{array}{c}0.08 \\
(0.10)\end{array}$ & $\begin{array}{c}0.25 \\
(0.16)\end{array}$ & $\begin{array}{c}0.10 \\
(0.10)\end{array}$ & $\begin{array}{l}0.32 * \\
(0.16)\end{array}$ \\
\hline $\begin{array}{l}\text { Collaboration with } \\
\text { universities }\end{array}$ & $\begin{array}{c}0.25 * * * \\
(0.09)\end{array}$ & $\begin{array}{c}0.18 \\
(0.15)\end{array}$ & $\begin{array}{c}0.24 * * * \\
(0.09)\end{array}$ & $\begin{array}{c}0.10 \\
(0.16)\end{array}$ & $\begin{array}{l}0.22 * * \\
(0.09)\end{array}$ & $\begin{array}{c}0.10 \\
(0.16)\end{array}$ & $\begin{array}{c}0.23^{* *} \\
(0.09)\end{array}$ & $\begin{array}{c}0.15 \\
(0.16)\end{array}$ \\
\hline East Germany & $\begin{array}{l}-0.11 \\
(0.10)\end{array}$ & $\begin{array}{l}-0.25 \\
(0.20)\end{array}$ & $\begin{array}{l}-0.09 \\
(0.11)\end{array}$ & $\begin{array}{l}-0.11 \\
(0.21)\end{array}$ & $\begin{array}{l}-0.05 \\
(0.11)\end{array}$ & $\begin{array}{l}-0.11 \\
(0.21)\end{array}$ & $\begin{array}{l}-0.05 \\
(0.11)\end{array}$ & $\begin{array}{l}-0.17 \\
(0.21)\end{array}$ \\
\hline Fragmentation index & $\begin{array}{c}1.48 \\
(1.54)\end{array}$ & $\begin{array}{l}-2.32 \\
(2.46)\end{array}$ & $\begin{array}{c}0.01 \\
(1.65)\end{array}$ & $\begin{array}{l}-3.57 \\
(2.62)\end{array}$ & $\begin{array}{c}-0.32 \\
(1.65)\end{array}$ & $\begin{array}{l}-3.40 \\
(2.73)\end{array}$ & $\begin{array}{l}-0.17 \\
(1.66)\end{array}$ & $\begin{array}{l}-2.53 \\
(2.66)\end{array}$ \\
\hline Pre-empted patents & & & $\begin{array}{c}0.38 * * * \\
(0.14)\end{array}$ & & $\begin{array}{c}0.38 * * * \\
(0.14)\end{array}$ & $\begin{array}{l}-0.05 \\
(0.22)\end{array}$ & $\begin{array}{c}0.36^{* *} \\
(0.14)\end{array}$ & $\begin{array}{l}-0.06 \\
(0.22)\end{array}$ \\
\hline Infringement & & & & $\begin{array}{c}0.83 * * * \\
(0.15)\end{array}$ & $\begin{array}{c}0.34 * * * \\
(0.10)\end{array}$ & $\begin{array}{c}0.85 * * * \\
(0.15)\end{array}$ & & \\
\hline Infringement (unprotected) & & & & & & & $\begin{array}{c}0.15 \\
(0.16)\end{array}$ & $\begin{array}{c}0.25 \\
(0.24)\end{array}$ \\
\hline Infringement (protected) & & & & & & & $\begin{array}{c}0.43^{* * *} \\
(0.12)\end{array}$ & $\begin{array}{c}0.74 * * * \\
(0.16)\end{array}$ \\
\hline Constant & $\begin{array}{c}-2.34 * * * \\
(0.27)\end{array}$ & $\begin{array}{c}-4.24 * * * \\
(0.48)\end{array}$ & $\begin{array}{c}-2.22 * * * \\
(0.27) \\
\end{array}$ & $\begin{array}{c}-4.26 * * * \\
(0.50)\end{array}$ & $\begin{array}{c}-2.22 * * * \\
(0.27)\end{array}$ & $\begin{array}{c}-4.28 * * * \\
(0.51)\end{array}$ & $\begin{array}{c}-2.17 * * * \\
(0.28)\end{array}$ & $\begin{array}{c}-4.14^{* * *} \\
(0.51)\end{array}$ \\
\hline $\mathrm{N}$ & 1162 & 1162 & 1162 & 1162 & 1162 & 1162 & 1162 & 1162 \\
\hline $\mathrm{Ll}$ & -565.16 & -209.79 & -561.61 & -193.79 & -556.24 & -193.77 & -555.51 & -199.63 \\
\hline $\begin{array}{l}\text { Reported figures are coeffi } \\
* * *(* *, *) \text { indicate a signi } \\
\text { Industry dummies are inclu }\end{array}$ & $\begin{array}{l}\text { ts; standa } \\
\text { nce level } \\
\text {, but not }\end{array}$ & $\begin{array}{l}\% \text { (5\%, } \\
\text { orted. }\end{array}$ & $\begin{array}{l}\text { rentheses } \\
\%) \text {. }\end{array}$ & & & & & \\
\hline
\end{tabular}


Table 3 shows results from probit regressions in which the technological context is taken into account. Models 9 to 12 report the interaction effects between fragmentation and pre-empted and infringed patents, respectively. We find a negative interaction effect between fragmentation and pre-empted patents for the in-licensing decision. This finding indicates that, although pre-empted patents increase the likelihood to license in technology, this likelihood is reduced when fragmentation increases. This suggests that markets for technology actually do not work well in case the firm experienced pre-empted patents and fragmentation. We can attribute this finding to high transaction costs that occur when licensing contracts are to be negotiated in a fragmented field of technology. The transaction cost in this case foreclose a firm's ability to license in a required technology and hence to appropriate the returns from invention (Graff et al., 2003). Moreover, it turns out that fragmentation does not moderate the effect of infringement on cross-licensing. This finding may be attributed to the ability of the infringed firm to sue a rival and to negotiate favorable licensing terms independent of how fragmented the field of technology is.

Models 13 to 16 show the results when we distinguish between firms in discrete versus firms in complex product industries. As the distinction between discrete and complex product industries has been argued to proxy for the level of fragmentation (Cohen et al., 2000), we do not include the fragmentation measure in these models. The results show little difference between the two groups of industries. The previous result on pre-empted patents holds in both contexts: we find positive effects on in-licensing. Contrary to what the interaction with the fragmentation index would have suggested, we do not find that in-licensing as a reaction to pre-empted patents actually becomes less likely in complex product industries. There is a positive significant effect on in-licensing for both discrete and complex product industries. When the effect of infringement is considered it turns out that infringement of protected IP increases the likelihood of cross-licensing in discrete and complex product industries. However, the effect in discrete product industries disappears altogether when marginal effects are considered (Table 6). ${ }^{3}$ In that sense, we find important differences between operating in a fragmented field of technology and in an industry characterized by complex products. The finding also cautions against equating an industry characteristic with a technology characteristic in a licensing context.

\footnotetext{
${ }^{3}$ Since probit models are non-linear models, the level of significance of marginal effects may differ from that of coefficients.
} 
Looking at the control variables in Table 2 and Table 3, we find consistent results across all model specifications. The patent stock of firms is as expected a strong predictor of firms' involvement in markets for technology. Cross-licensing, of course, depends on the ownership of patents. A strong patent position further seems to shield firms from having to license in technology themselves. Higher R\&D intensity as well as larger firm size are both strong and significant predictors of in- and cross-licensing. Moreover, several effects of collaboration can be observed. Particularly, and as expected, we find that collaboration with competitors increases the likelihood to engage in cross-licensing while collaboration with universities increases the likelihood of in-licensing. No significant effects can be observed for the remaining control variables. 
Table 3: Probit models for in- and cross-licensing (cont.)

\begin{tabular}{|c|c|c|c|c|c|c|c|c|}
\hline & 9 & 10 & 11 & 12 & 13 & 14 & 15 & 16 \\
\hline & & & & & \multicolumn{2}{|c|}{ Discrete industries } & \multicolumn{2}{|c|}{ Complex industries } \\
\hline & $\begin{array}{c}\text { In- } \\
\text { licensing }\end{array}$ & $\begin{array}{l}\text { Cross- } \\
\text { licensing }\end{array}$ & $\begin{array}{c}\text { In- } \\
\text { licensing }\end{array}$ & $\begin{array}{l}\text { Cross- } \\
\text { licensing }\end{array}$ & $\begin{array}{c}\text { In- } \\
\text { licensing }\end{array}$ & $\begin{array}{l}\text { Cross- } \\
\text { licensing }\end{array}$ & $\begin{array}{c}\text { In- } \\
\text { licensing }\end{array}$ & $\begin{array}{l}\text { Cross- } \\
\text { licensing }\end{array}$ \\
\hline Log(employment) & $\begin{array}{c}0.14^{* * *} \\
(0.03)\end{array}$ & $\begin{array}{c}0.29 * * * \\
(0.06)\end{array}$ & $\begin{array}{c}0.16^{* * *} \\
(0.03)\end{array}$ & $\begin{array}{c}0.31^{* * *} \\
(0.05)\end{array}$ & $\begin{array}{c}0.13^{* *} \\
(0.05)\end{array}$ & $\begin{array}{c}0.35^{* * *} \\
(0.10)\end{array}$ & $\begin{array}{c}0.18^{* * *} \\
(0.05)\end{array}$ & $\begin{array}{c}0.31^{* * *} \\
(0.07)\end{array}$ \\
\hline R\&D/ employment & $\begin{array}{c}8.10 * * * \\
(2.37)\end{array}$ & $\begin{array}{l}6.29 * * \\
(2.68)\end{array}$ & $\begin{array}{c}8.55^{* * *} \\
(2.39)\end{array}$ & $\begin{array}{c}6.85 * * \\
(2.68)\end{array}$ & $\begin{array}{l}7.32 * * \\
(3.63)\end{array}$ & $\begin{array}{c}14.07 * * \\
(6.08)\end{array}$ & $\begin{array}{c}9.27 * * * \\
(3.27)\end{array}$ & $\begin{array}{c}5.11 \\
(3.39)\end{array}$ \\
\hline Patentstock/ empl. & $\begin{array}{l}-0.20 \\
(0.74)\end{array}$ & $\begin{array}{c}2.28 * * * \\
(0.83)\end{array}$ & $\begin{array}{c}0.11 \\
(0.72)\end{array}$ & $\begin{array}{c}2.66^{* * *} \\
(0.82)\end{array}$ & $\begin{array}{c}0.15 \\
(0.83)\end{array}$ & $\begin{array}{c}2.34^{* *} \\
(0.96)\end{array}$ & $\begin{array}{l}-0.92 \\
(1.64)\end{array}$ & $\begin{array}{c}3.28 \\
(2.06)\end{array}$ \\
\hline Export dummy & $\begin{array}{c}-.14 \\
(0.14)\end{array}$ & $\begin{array}{c}0.08 \\
(0.25)\end{array}$ & $\begin{array}{l}-0.16 \\
(0.14)\end{array}$ & $\begin{array}{c}0.08 \\
(0.26)\end{array}$ & $\begin{array}{l}-0.01 \\
(0.19)\end{array}$ & $\begin{array}{l}-0.08 \\
(0.45)\end{array}$ & $\begin{array}{l}-0.29 \\
(0.20)\end{array}$ & $\begin{array}{l}-0.00 \\
(0.33)\end{array}$ \\
\hline Part of a firm group & $\begin{array}{c}0.15 \\
(0.10)\end{array}$ & $\begin{array}{c}0.12 \\
(0.17)\end{array}$ & $\begin{array}{c}0.14 \\
(0.10)\end{array}$ & $\begin{array}{c}0.10 \\
(0.17)\end{array}$ & $\begin{array}{c}0.16 \\
(0.15)\end{array}$ & $\begin{array}{c}0.22 \\
(0.33)\end{array}$ & $\begin{array}{c}0.12 \\
(0.14)\end{array}$ & $\begin{array}{c}0.08 \\
(0.21)\end{array}$ \\
\hline Collaboration B2B & $\begin{array}{c}0.12 \\
(0.13)\end{array}$ & $\begin{array}{c}0.08 \\
(0.22)\end{array}$ & $\begin{array}{c}0.11 \\
(0.13)\end{array}$ & $\begin{array}{c}0.04 \\
(0.22)\end{array}$ & $\begin{array}{c}0.27 \\
(0.20)\end{array}$ & $\begin{array}{c}0.67 \\
(0.55)\end{array}$ & $\begin{array}{l}-0.04 \\
(0.17)\end{array}$ & $\begin{array}{l}-0.04 \\
(0.26)\end{array}$ \\
\hline Collaboration B2C & $\begin{array}{c}0.38 * * * \\
(0.10)\end{array}$ & $\begin{array}{c}0.03 \\
(0.16)\end{array}$ & $\begin{array}{c}0.39 * * * \\
(0.10)\end{array}$ & $\begin{array}{c}0.06 \\
(0.16)\end{array}$ & $\begin{array}{c}0.55^{* * *} \\
(0.14)\end{array}$ & $\begin{array}{l}-0.36 \\
(0.27)\end{array}$ & $\begin{array}{c}0.17 \\
(0.15)\end{array}$ & $\begin{array}{c}0.25 \\
(0.21)\end{array}$ \\
\hline $\begin{array}{l}\text { Collaboration with } \\
\text { material suppliers }\end{array}$ & $\begin{array}{c}0.06 \\
(0.10)\end{array}$ & $\begin{array}{c}0.17 \\
(0.17)\end{array}$ & $\begin{array}{c}0.06 \\
(0.10)\end{array}$ & $\begin{array}{c}0.16 \\
(0.17)\end{array}$ & $\begin{array}{c}0.07 \\
(0.14)\end{array}$ & $\begin{array}{l}0.69 * \\
(0.40)\end{array}$ & $\begin{array}{c}0.05 \\
(0.14)\end{array}$ & $\begin{array}{c}0.09 \\
(0.20)\end{array}$ \\
\hline $\begin{array}{l}\text { Collaboration with } \\
\text { service suppliers }\end{array}$ & $\begin{array}{c}0.01 \\
(0.09)\end{array}$ & $\begin{array}{c}0.18 \\
(0.15)\end{array}$ & $\begin{array}{c}0.01 \\
(0.09)\end{array}$ & $\begin{array}{c}0.19 \\
(0.15)\end{array}$ & $\begin{array}{c}0.02 \\
(0.13)\end{array}$ & $\begin{array}{l}-0.13 \\
(0.25)\end{array}$ & $\begin{array}{c}0.03 \\
(0.13)\end{array}$ & $\begin{array}{l}0.34^{*} \\
(0.19)\end{array}$ \\
\hline $\begin{array}{l}\text { Collaboration with } \\
\text { competitors }\end{array}$ & $\begin{array}{c}0.12 \\
(0.11)\end{array}$ & $\begin{array}{l}0.34 * * \\
(0.16)\end{array}$ & $\begin{array}{c}0.08 \\
(0.10)\end{array}$ & $\begin{array}{c}0.25 \\
(0.16)\end{array}$ & $\begin{array}{l}0.29 * * \\
(0.14)\end{array}$ & $\begin{array}{l}0.53^{* *} \\
(0.27)\end{array}$ & $\begin{array}{l}-0.11 \\
(0.16)\end{array}$ & $\begin{array}{c}0.16 \\
(0.22)\end{array}$ \\
\hline $\begin{array}{l}\text { Collaboration with } \\
\text { universities }\end{array}$ & $\begin{array}{l}0.22^{* *} \\
(0.10)\end{array}$ & $\begin{array}{c}0.15 \\
(0.16)\end{array}$ & $\begin{array}{l}0.22 * * \\
(0.09)\end{array}$ & $\begin{array}{c}0.10 \\
(0.16)\end{array}$ & $\begin{array}{l}0.26 * * \\
(0.13)\end{array}$ & $\begin{array}{l}0.80 * * \\
(0.31)\end{array}$ & $\begin{array}{c}0.21 \\
(0.14)\end{array}$ & $\begin{array}{l}-0.22 \\
(0.21)\end{array}$ \\
\hline East Germany & $\begin{array}{l}-0.03 \\
(0.11)\end{array}$ & $\begin{array}{l}-0.16 \\
(0.21)\end{array}$ & $\begin{array}{l}-0.05 \\
(0.11)\end{array}$ & $\begin{array}{l}-0.11 \\
(0.21)\end{array}$ & $\begin{array}{l}-0.12 \\
(0.16)\end{array}$ & $\begin{array}{c}0.01 \\
(0.37)\end{array}$ & $\begin{array}{c}0.01 \\
(0.15)\end{array}$ & $\begin{array}{l}-0.29 \\
(0.27)\end{array}$ \\
\hline Fragmentation index & $\begin{array}{c}2.90 \\
(2.06)\end{array}$ & $\begin{array}{c}0.72 \\
(3.25)\end{array}$ & $\begin{array}{c}0.14 \\
(2.00)\end{array}$ & $\begin{array}{l}-1.58 \\
(3.99)\end{array}$ & & & & \\
\hline Pre-empted patents & $\begin{array}{c}0.65 * * * \\
(0.19)\end{array}$ & $\begin{array}{c}0.23 \\
(0.28)\end{array}$ & $\begin{array}{c}0.37 * * * \\
(0.14)\end{array}$ & $\begin{array}{l}-0.06 \\
(0.22)\end{array}$ & $\begin{array}{l}0.40^{* *} \\
(0.20)\end{array}$ & $\begin{array}{c}0.05 \\
(0.34)\end{array}$ & $\begin{array}{l}0.37 * * \\
(0.19)\end{array}$ & $\begin{array}{l}-0.30 \\
(0.29)\end{array}$ \\
\hline Infringement & & & $\begin{array}{c}0.37 * * * \\
(0.12)\end{array}$ & $\begin{array}{c}0.91^{* * *} \\
(0.18)\end{array}$ & & & & \\
\hline $\begin{array}{l}\text { Infringement } \\
\text { (unprotected) }\end{array}$ & $\begin{array}{c}0.12 \\
(0.16)\end{array}$ & $\begin{array}{c}0.24 \\
(0.24)\end{array}$ & & & $\begin{array}{c}0.10 \\
(0.27)\end{array}$ & $\begin{array}{c}0.07 \\
(0.45)\end{array}$ & $\begin{array}{c}0.21 \\
(0.20)\end{array}$ & $\begin{array}{c}0.36 \\
(0.29)\end{array}$ \\
\hline $\begin{array}{l}\text { Infringement } \\
\text { (protected) }\end{array}$ & $\begin{array}{c}0.42^{* * *} \\
(0.12)\end{array}$ & $\begin{array}{c}0.74 * * * \\
(0.16)\end{array}$ & & & $\begin{array}{c}0.25 \\
(0.20)\end{array}$ & $\begin{array}{c}0.94 * * * \\
(0.29)\end{array}$ & $\begin{array}{c}0.49 * * * \\
(0.16)\end{array}$ & $\begin{array}{c}0.64 * * * \\
(0.21)\end{array}$ \\
\hline $\begin{array}{l}\text { Fragmentation * } \\
\text { pre-empted patents }\end{array}$ & $\begin{array}{c}-9.22 * * \\
(3.81)\end{array}$ & $\begin{array}{l}-10.24 \\
(6.59)\end{array}$ & & & & & & \\
\hline $\begin{array}{l}\text { Fragmentation * } \\
\text { infringement }\end{array}$ & & & $\begin{array}{l}-1.26 \\
(3.10)\end{array}$ & $\begin{array}{l}-3.03 \\
(5.04)\end{array}$ & & & & \\
\hline Constant & $\begin{array}{c}-2.17^{* * * *} \\
(0.28)\end{array}$ & $\begin{array}{c}-4.16^{* * * *} \\
(0.51)\end{array}$ & $\begin{array}{c}-2.22 * * * \\
(0.28)\end{array}$ & $\begin{array}{c}-4.29 * * * \\
(0.52)\end{array}$ & $\begin{array}{c}-2.22 * * * \\
(0.37)\end{array}$ & $\begin{array}{c}-5.52 * * * \\
(1.08)\end{array}$ & $\begin{array}{c}-2.01 * * * \\
(0.37)\end{array}$ & $\begin{array}{c}-3.76 * * * \\
(0.61)\end{array}$ \\
\hline $\begin{array}{l}\mathrm{N} \\
\mathrm{ll}\end{array}$ & $\begin{array}{c}1162 \\
-565.16\end{array}$ & $\begin{array}{c}1162 \\
-209.79\end{array}$ & $\begin{array}{c}1162 \\
-561.61\end{array}$ & $\begin{array}{c}1162 \\
-209.79\end{array}$ & $\begin{array}{c}570 \\
-556.24\end{array}$ & $\begin{array}{c}570 \\
-193.77\end{array}$ & $\begin{array}{c}592 \\
-555.51\end{array}$ & $\begin{array}{c}592 \\
-199.63\end{array}$ \\
\hline $\begin{array}{l}\text { Reported figures are } \\
* * *(* *, *) \text { indicate } \\
\text { Industry dummies a }\end{array}$ & $\begin{array}{l}\text { flicients; } \\
\text { nificance } \\
\text { cluded, b }\end{array}$ & not rep & $\begin{array}{l}\text { rs in pare } \\
(5 \%, 10 \% \\
\text { d. }\end{array}$ & heses. & & & & \\
\hline
\end{tabular}

\section{Conclusion and future research}

Our research has demonstrated that both pre-empted and infringed patents matter considerably for a firm's participation in the market for technology in terms of in- and cross- 
licensing. Pre-empted patents significantly drive the in-licensing behavior of firms while infringement makes cross-licensing more likely. Interesting results emerge when we take a closer look at how these two major problems for appropriating the returns from innovation interact with the technology and industry context in which the firm is operating. Higher fragmentation actually decreases the likelihood of in-licensing as a reaction to pre-empted patents. We attribute this finding to prohibitively high transaction costs that result from high dispersion of patent ownership. Fragmentation does not, however, influence the effect of infringement on licensing. Infringement implies that the firm already holds the rights on IP which it subsequently tries to leverage in the market for technology, for example by negotiating favorable cross-licensing terms. Our results further show that it is not so much the fragmentation of technology areas that drives licensing activity (Cockburn et al., 2010) but rather the perceived problems in value appropriation that arise from pre-empted and infringed patents. In that sense, our study qualifies the results by Siebert and von Graevenitz (2010), who conclude that licensing is less effective in industries characterized by a high degree of fragmentation. We show that fragmentation needs to be more considered as an indirect effect in connection with pre-empted patents, rather than as having a direct effect on licensing activities. Moreover, our results show that the relationship between fragmentation of technologies and discrete versus complex product industries is not that clear-cut. We had expected to find similar effects to fragmentation in complex product industries which was, however, not the case.

Our research contributes to the literature in several ways. First, we are able to analyze not only in-licensing but we take account of joint in- and cross-licensing activities, extending prior findings by Cockburn et al. (2010), Siebert and von Graevenitz (2010) and Galasso (2012). Hence, our analysis provides a more complete picture of a firm's involvement in the market for technology. Moreover, our research contributes to the few studies that look into the extent of patent infringement and its consequences (Weatherall et al., 2009; Galasso, 2012). We analyze the relationship between infringement and cross-licensing activities of firms in a broad cross-industry sample, contributing to a better understanding of what factors actually drive a firm's participation in markets for technology. Second, our analysis reflects the characteristics of both the patent landscape and product industry that firms experience by accounting for fragmentation of technology areas and complex versus discrete product industries (Cohen et al., 2000; Ziedonis, 2004). Our research thus provides a more nuanced understanding of the effects of pre-empted and infringed patents on both in- and cross- 
licensing while acknowledging the conditions under which those effects are likely to emerge. Third, our research combines survey data from a large sample of the manufacturing sector in Germany with patent data from the EPO which enables a precise identification of pre-empted patents by making use of the information recorded during the patent examination procedure.

Our research is, however, limited by the data that is available to us. We do not have information on whether the firm has only engaged in out-licensing and not necessarily crosslicensing. Moreover, we can only observe whether a firm is engaged in licensing or not. Hence, we miss information on the number of licenses a firm sells or acquires and the nature of the technologies that are licensed, e.g. whether licensed technologies are core to the firm versus non-core technologies. Moreover, we do not have information on the licensing partner and a detailed description of the actual licensing contract. Also, we do not observe the motivation for licensing and the returns to licensing activities. Firms might for instance license to rivals in order to increase their costs via royalties (Shapiro, 1985; Wang, 1998). Future research could address these limitations in order to further our understanding of the drivers of firms’ licensing decisions.

Acknowledgements: We thank Dirk Czarnitzki, Georg von Graevenitz, Georg Licht, Christian Rammer, Cédric Schneider, Tanya Tanayama, Alexandra Zaby and three anonymous reviewers for helpful discussions and comments on earlier drafts of the paper. 


\section{References}

Amara, N., R. Landry and N. Traoré (2008), Managing the Protection of Innovations in Knowledge-Intensive Business Services, Research Policy 37, 1530-1547.

Arora, A., A. Fosfuri and A. Gambardella (1999), Markets for Technology (Why Do We See Them, Why We Don't See More of Them, and Why We Should Care), Universidad Carlos III, Working Paper No. 99-17(4), Madrid.

Arora, A., A. Fosfuri and A. Gambardella (2004), Markets for Technology: The Economics of Innovation and Corporate Strategy, Cambridge, MA.

Arora, A. and A. Gambardella (2010), Ideas for Rent: An Overview of Markets for Technology, Industrial and Corporate Change 19 (3), 775-803.

Arundel, A., G. van de Paal and L. Soete (1995), Innovation Strategies of Europe's Largest Industrial Firms, MERIT No., Maastricht.

Blind, K., K. Cremers and E. Müller (2009), The Influence of Strategic Patenting on Companies' Patent Portfolios, Research Policy 38 (2), 428-436.

Blind, K., J. Edler, R. Frietsch and U. Schmooch (2006), Motives to Patent: Empirical Evidence from Germany, Research Policy 35, 655-672.

Cockburn, I.M., M.J. MacGarvie and E. Müller (2010), Patent Thickets, Licensing and Innovative Performance, Industrial \& Corporate Change 19 (3), 899-925.

Cohen, W.M., R.R. Nelson and J.P. Walsh (2000), Protecting Their Intellectual Assets: Appropriability Conditions and Why U.S. Manufacturing Firms Patent (or Not), NBER Working Paper No. 7552, Cambridge, MA.

David, P. (2001), Will Building "Good Fences" Really Make "Good Neighbours" in Science?, Stanford University, Department of Economics Working Paper No. 01-005, Stanford, CA.

Duguet, E. and I. Kabla (1998), Appropriation Strategy and the Motivations to Use the Patent System: An Econometric Analysis at the Firm Level in French Manufacturing, Annales d'Economie et de Statistique 49/50, 289-327.

Encaoua, D., D. Guellec and C. Martinez (2006), Patent Systems for Encouraging Innovation: Lessons from Economic Analysis, Research Policy 35 (9), 1423-1440.

Galasso, A. (2012), Broad Cross-License Negotiations, Journal of Economics and Management Strategy 21 (4), 873-911.

Gallini, N.T. (2002), The Economics of Patents: Lessons from Recent U.S. Patent Reform, Journal of Economic Perspectives 16 (2), 131-154.

Graff, G.D., G.C. Rausser and A.A. Small (2003), Agricultural Biotechnology's Complementary Intellectual Assets, The Review of Economics and Statistics 85 (2), 349-363.

Grimpe, C. and K. Hussinger (2008), Pre-Empting Technology Competition through Firm Acquisitions, Economics Letters 100 (2), 189-191.

Grimpe, C. and U. Kaiser (2010), Balancing Internal and External Knowledge Acquisition: The Gains and Pains from R\&D Outsourcing, Journal of Management Studies 47 (8), 1483-1509. 
Guellec, D., C. Martinez and M.P. Zuniga (2012), Pre-Emptive Patenting: Securing Market Exclusion and Freedom of Operation, Economics of Innovation and New Technology 21 (1), 1-29.

Hall, B.H. (1990), The Manufacturing Sector Master File: 1959-1987, NBER Working Paper No. 3366, Cambridge, MA.

Harhoff, D., K. Hoisl and C. Webb (2005), European Patent Citations. How to Count and How to Interpret Them, LMU Discussion Papers No., Munich.

Heller, M.A. and R.S. Eisenberg (1998), Can Patents Deter Innovation? The Anticommons in Biomedical Research Science 280 (5364), 698-701.

Horstmann, I., G.M. MacDonald and A. Slivinski (1985), Patents as Information Transfer Mechanisms: To Patent or (Maybe) Not to Patent, Journal of Political Economy 93, 837-858.

Jaffe, A. and J. Lerner (2004), Innovation and Its Discontents: How Our Broken Patent System Is Endangering Innovation and Progress, and What to Do About It, Princeton, NJ.

Kingston, W. (2004), Making Patents Useful to Small Firms, Intellectual Property Quarterly 2004, 369-378.

Lanjouw, J.O. and M. Schankerman (1997), Stylized Facts of Patent Litigation: Value, Scope and Ownership, NBER Working Paper No. W6297, Cambridge, MA.

Laursen, K. and A. Salter (2006), Open for Innovation: The Role of Openness in Explaining Innovation Performance among U.K. Manufacturing Firms, Strategic Management Journal 27, 131-150.

Levin, R.C., A.K. Klevoric, R.R. Nelson and S.G. Winter (1987), Appropriating the Returns from Industrial Research and Development, Brookings Papers on Economic Activity 3, 783-831.

Merges, R.P. and R.R. Nelson (1990), On the Complex Economics of Patent Scope, Columbia Law Review 90 (4), 839-916.

Meurer, M.J. (1989), The Settlement of Patent Litigation, RAND Journal of Economics 20, 77-91.

Reitzig, M. (2004), The Private Values of 'Thickets' and 'Fences': Towards an Updated Picture of the Use of Patents across Industries, Economics of Innovation and New Technologies 13 (5), 457-476.

Schneider, C. (2008), Fences and Competition in Patent Races, International Journal of Industrial Organization 26 (6), 1348-1364.

Scotchmer, S. (1991), Standing on the Shoulders of Giants: Cumulative Research and the Patent Law, Journal of Economic Perspectives 5 (1), 29-41.

Scotchmer, S. (2004), Innovation and Incentives, Cambridge, MA.

Shapiro, C. (1985), Patent Licensing and R\&D Rivalry, American Economic Review 75 (2), 25-30.

Shapiro, C. (2001), Navigating the Patent Thicket: Cross Licenses, Patent Pools, and Standard Setting, in: Jaffe, A., J. Lerner and S. Stern (eds.), Innovation Policy and the Economy, Cambridge, MA, 119-150. 
Siebert, R. and G. von Graevenitz (2010), Jostling for Advantage: Licensing and Entry into Patent Portfolio Races, Journal of Economic Behavior \& Organization 73 (2), 225245.

Somaya, D. and D.J. Teece (2000), Combining Incentives in Multi-Innovation Products: Organizational Choices, Patents and Public Policy, Haas School of Business Working Paper, University of California No., Berkeley.

von Graevenitz, G., S. Wagner and D. Harhoff (2008), Incidence and Growth of Patent Thickets - the Impact of Technological Opportunities and Complexity, CEPR Discussion Paper No. 6900, London.

von Graevenitz, G., S. Wagner and D. Harhoff (2012), Incidence and Growth of Patent Thickets - the Impact of Technological Opportunities and Complexity., Journal of Industrial Economics forthcoming.

Wang, X.H. (1998), Fees Versus Royalties in a Cournot Duopoly, Economics Letters 60 (1), 55-62.

Waterson, M. (1990), The Economics of Product Patents, American Economic Review 80 (4), 860-869.

Weatherall, K. and E. Webster (2009), Patent Infringement in Australia: Results from a Survey, Intellectual Property Research Institute of Australia Working Paper No., Melbourne.

Weatherall, K., E. Webster and L. Bently (2009), Ip Enforcement in the Uk and Beyond: A Literature Review, SABIP Report No. EC001, London.

Webb, C., H. Dernis, D. Harhoff and K. Hoisl (2005), Analyzing European and International Patent Citations: A Set of Epo Database Building Blocks, OECD STI Working Paper No. 2005/9, Paris.

Ziedonis, R.H. (2004), Don't Fence Me In: Fragmented Markets for Technology and the Patent Acquisition Strategies of Firms, Management Science 50 (6), 804-820. 


\section{Appendix}

Table 4: Bivariate correlations

\begin{tabular}{|c|c|c|c|c|c|c|c|c|c|c|c|c|c|c|c|c|c|c|c|}
\hline & & 1 & 2 & 3 & 4 & 5 & 6 & 7 & 8 & 9 & 10 & 11 & 12 & 13 & 14 & 15 & 16 & 17 & 18 \\
\hline 1 & In-licensing & & & & & & & & & & & & & & & & & & \\
\hline 2 & Cross-licensing & 0.27 & & & & & & & & & & & & & & & & & \\
\hline 3 & Log(emplyment) & 0.27 & 0.34 & & & & & & & & & & & & & & & & \\
\hline 4 & $\mathrm{R} \& \mathrm{D} /$ employment & 0.13 & 0.07 & -0.08 & & & & & & & & & & & & & & & \\
\hline 5 & Patentstock/ employment & 0.06 & 0.11 & -0.02 & 0.18 & & & & & & & & & & & & & & \\
\hline 6 & Pre-empted patents & 0.21 & 0.18 & 0.39 & 0.07 & 0.24 & & & & & & & & & & & & & \\
\hline 7 & Infringement & 0.19 & 0.29 & 0.26 & 0.04 & 0.05 & 0.18 & & & & & & & & & & & & \\
\hline 8 & Infringement (unprotected) & 0.01 & -0.01 & -0.01 & -0.01 & -0.01 & 0.02 & 0.53 & & & & & & & & & & & \\
\hline 9 & Infringement (protected) & 0.21 & 0.28 & 0.30 & 0.04 & 0.03 & 0.21 & 0.67 & -0.13 & & & & & & & & & & \\
\hline 10 & Fragmentation index & 0.10 & 0.04 & 0.17 & 0.14 & 0.13 & 0.41 & 0.17 & 0.09 & 0.11 & & & & & & & & & \\
\hline 11 & Export dummy & -0.03 & -0.02 & 0.03 & 0.02 & 0.03 & 0.08 & 0.07 & 0.05 & 0.04 & 0.09 & & & & & & & & \\
\hline 12 & Part of a group & 0.17 & 0.17 & 0.52 & 0.00 & 0.02 & 0.21 & 0.12 & 0.02 & 0.12 & 0.11 & 0.06 & & & & & & & \\
\hline 13 & Collaboration B2B & 0.06 & 0.04 & 0.01 & 0.02 & -0.01 & 0.02 & 0.05 & 0.04 & 0.02 & -0.02 & -0.01 & 0.06 & & & & & & \\
\hline 14 & Collaboration B2C & 0.12 & 0.01 & -0.01 & -0.02 & 0.04 & 0.01 & 0.01 & 0.01 & 0.03 & -0.04 & -0.07 & -0.06 & 0.14 & & & & & \\
\hline 15 & Collaboration with material suppliers & 0.09 & 0.10 & 0.18 & -0.04 & 0.01 & 0.07 & 0.04 & -0.01 & 0.07 & 0.02 & 0.00 & 0.15 & 0.23 & 0.09 & & & & \\
\hline 16 & Collaboration with service suppliers & 0.08 & 0.11 & 0.11 & 0.06 & 0.04 & 0.09 & 0.05 & -0.02 & 0.08 & 0.07 & -0.07 & 0.09 & 0.02 & 0.04 & 0.20 & & & \\
\hline 17 & Collaboration with competitors & 0.07 & 0.07 & 0.03 & 0.01 & 0.04 & 0.04 & -0.01 & 0.02 & -0.06 & 0.06 & -0.04 & 0.07 & 0.12 & 0.18 & 0.09 & 0.05 & & \\
\hline 18 & Collaboration with universities & 0.15 & 0.12 & 0.22 & 0.15 & 0.07 & 0.14 & 0.15 & 0.08 & 0.10 & 0.12 & 0.02 & 0.13 & 0.09 & -0.04 & 0.07 & 0.10 & 0.09 & \\
\hline 19 & East Germany & -0.11 & -0.11 & -0.27 & -0.01 & -0.07 & -0.20 & -0.17 & -0.06 & -0.16 & -0.12 & -0.05 & -0.12 & -0.03 & 0.00 & -0.07 & 0.00 & -0.01 & 0.04 \\
\hline
\end{tabular}


Table 5: Marginal effects after probit regressions

\begin{tabular}{|c|c|c|c|c|c|c|c|c|}
\hline & 1 & 2 & 3 & 4 & 5 & 6 & 7 & 8 \\
\hline & $\begin{array}{c}\text { In- } \\
\text { licensing }\end{array}$ & $\begin{array}{l}\text { Cross- } \\
\text { licensing }\end{array}$ & $\begin{array}{c}\text { In- } \\
\text { licensing }\end{array}$ & $\begin{array}{l}\text { Cross- } \\
\text { licensing }\end{array}$ & $\begin{array}{c}\text { In- } \\
\text { licensing }\end{array}$ & $\begin{array}{l}\text { Cross- } \\
\text { licensing }\end{array}$ & $\begin{array}{c}\text { In- } \\
\text { licensing }\end{array}$ & $\begin{array}{l}\text { Cross- } \\
\text { licensing }\end{array}$ \\
\hline Log(employment) & $\begin{array}{c}0.06^{* * * *} \\
(0.01)\end{array}$ & $\begin{array}{c}0.02^{* * *} \\
(0.00)\end{array}$ & $\begin{array}{c}0.05^{* * * *} \\
(0.01)\end{array}$ & $\begin{array}{c}0.02 * * * \\
(0.00)\end{array}$ & $\begin{array}{c}0.05^{* * *} \\
(0.01)\end{array}$ & $\begin{array}{c}0.02 * * * \\
(0.00)\end{array}$ & $\begin{array}{c}0.04 * * * \\
(0.01)\end{array}$ & $\begin{array}{c}0.02 * * * \\
(0.00)\end{array}$ \\
\hline R\&D/ employment & $\begin{array}{c}2.49 * * * \\
(0.70)\end{array}$ & $\begin{array}{c}0.40 * * \\
(0.17)\end{array}$ & $\begin{array}{c}2.54 * * * \\
(0.71)\end{array}$ & $\begin{array}{l}0.36 * * \\
(0.15)\end{array}$ & $\begin{array}{c}2.51 * * * \\
(0.71)\end{array}$ & $\begin{array}{c}0.37 * * \\
(0.15)\end{array}$ & $\begin{array}{c}2.46 * * * \\
(0.70)\end{array}$ & $\begin{array}{c}0.38 * * \\
(0.16)\end{array}$ \\
\hline Patentstock/ employment & $\begin{array}{c}0.16 \\
(0.21)\end{array}$ & $\begin{array}{c}0.16^{* * * *} \\
(0.05)\end{array}$ & $\begin{array}{c}0.03 \\
(0.21)\end{array}$ & $\begin{array}{c}0.14^{* * * *} \\
(0.05)\end{array}$ & $\begin{array}{c}0.03 \\
(0.21)\end{array}$ & $\begin{array}{c}0.14^{* * * *} \\
(0.05)\end{array}$ & $\begin{array}{c}0.03 \\
(0.21)\end{array}$ & $\begin{array}{c}0.15^{* * * *} \\
(0.05)\end{array}$ \\
\hline Export dummy & $\begin{array}{l}-0.04 \\
(0.04)\end{array}$ & $\begin{array}{c}0.01 \\
(0.01)\end{array}$ & $\begin{array}{l}-0.04 \\
(0.04)\end{array}$ & $\begin{array}{c}0.00 \\
(0.01)\end{array}$ & $\begin{array}{l}-0.05 \\
(0.04)\end{array}$ & $\begin{array}{c}0.00 \\
(0.01)\end{array}$ & $\begin{array}{l}-0.05 \\
(0.04)\end{array}$ & $\begin{array}{c}0.00 \\
(0.01)\end{array}$ \\
\hline Part of a group & $\begin{array}{c}0.04 \\
(0.03)\end{array}$ & $\begin{array}{c}0.01 \\
(0.01)\end{array}$ & $\begin{array}{c}0.04 \\
(0.03)\end{array}$ & $\begin{array}{c}0.01 \\
(0.01)\end{array}$ & $\begin{array}{c}0.04 \\
(0.03)\end{array}$ & $\begin{array}{c}0.01 \\
(0.01)\end{array}$ & $\begin{array}{c}0.04 \\
(0.03)\end{array}$ & $\begin{array}{c}0.01 \\
(0.01)\end{array}$ \\
\hline Collaboration B2B & $\begin{array}{c}0.04 \\
(0.03)\end{array}$ & $\begin{array}{c}0.01 \\
(0.01)\end{array}$ & $\begin{array}{c}0.04 \\
(0.03)\end{array}$ & $\begin{array}{c}0.00 \\
(0.01)\end{array}$ & $\begin{array}{c}0.03 \\
(0.04)\end{array}$ & $\begin{array}{c}0.00 \\
(0.01)\end{array}$ & $\begin{array}{c}0.03 \\
(0.04)\end{array}$ & $\begin{array}{c}0.00 \\
(0.01)\end{array}$ \\
\hline Collaboration B2C & $\begin{array}{c}0.13^{* * * *} \\
(0.03)\end{array}$ & $\begin{array}{c}0.00 \\
(0.01)\end{array}$ & $\begin{array}{c}0.12 * * * \\
(0.03)\end{array}$ & $\begin{array}{c}0.00 \\
(0.01)\end{array}$ & $\begin{array}{c}0.12^{* * * *} \\
(0.03)\end{array}$ & $\begin{array}{c}0.00 \\
(0.01)\end{array}$ & $\begin{array}{c}0.12 * * * \\
(0.03)\end{array}$ & $\begin{array}{c}0.00 \\
(0.01)\end{array}$ \\
\hline $\begin{array}{l}\text { Collaboration with } \\
\text { material suppliers }\end{array}$ & $\begin{array}{c}0.02 \\
(0.03)\end{array}$ & $\begin{array}{c}0.01 \\
(0.01)\end{array}$ & $\begin{array}{c}0.02 \\
(0.03)\end{array}$ & $\begin{array}{c}0.01 \\
(0.01)\end{array}$ & $\begin{array}{c}0.02 \\
(0.03)\end{array}$ & $\begin{array}{c}0.01 \\
(0.01)\end{array}$ & $\begin{array}{c}0.02 \\
(0.03)\end{array}$ & $\begin{array}{c}0.01 \\
(0.01)\end{array}$ \\
\hline $\begin{array}{l}\text { Collaboration with } \\
\text { service suppliers }\end{array}$ & $\begin{array}{c}0.01 \\
(0.03)\end{array}$ & $\begin{array}{c}0.01 \\
(0.01)\end{array}$ & $\begin{array}{c}0.01 \\
(0.03)\end{array}$ & $\begin{array}{c}0.01 \\
(0.01)\end{array}$ & $\begin{array}{c}0.00 \\
(0.03)\end{array}$ & $\begin{array}{c}0.01 \\
(0.01)\end{array}$ & $\begin{array}{c}0.00 \\
(0.03)\end{array}$ & $\begin{array}{c}0.01 \\
(0.01)\end{array}$ \\
\hline $\begin{array}{l}\text { Collaboration with } \\
\text { competitors }\end{array}$ & $\begin{array}{c}0.02 \\
(0.03)\end{array}$ & $\begin{array}{c}0.02 \\
(0.01)\end{array}$ & $\begin{array}{c}0.02 \\
(0.03)\end{array}$ & $\begin{array}{c}0.01 \\
(0.01)\end{array}$ & $\begin{array}{c}0.02 \\
(0.03)\end{array}$ & $\begin{array}{c}0.02 \\
(0.01)\end{array}$ & $\begin{array}{c}0.03 \\
(0.03)\end{array}$ & $\begin{array}{c}0.02 \\
(0.01)\end{array}$ \\
\hline $\begin{array}{l}\text { Collaboration with } \\
\text { universities }\end{array}$ & $\begin{array}{c}0.07 * * * \\
(0.03)\end{array}$ & $\begin{array}{c}0.01 \\
(0.01)\end{array}$ & $\begin{array}{c}0.07 * * * \\
(0.03)\end{array}$ & $\begin{array}{c}0.01 \\
(0.01)\end{array}$ & $\begin{array}{l}0.06 * * \\
(0.03)\end{array}$ & $\begin{array}{c}0.01 \\
(0.01)\end{array}$ & $\begin{array}{l}0.07 * * \\
(0.03)\end{array}$ & $\begin{array}{c}0.01 \\
(0.01)\end{array}$ \\
\hline East Germany & $\begin{array}{l}-0.03 \\
(0.03)\end{array}$ & $\begin{array}{l}-0.01 \\
(0.01)\end{array}$ & $\begin{array}{l}-0.03 \\
(0.03)\end{array}$ & $\begin{array}{l}-0.01 \\
(0.01)\end{array}$ & $\begin{array}{l}-0.01 \\
(0.03)\end{array}$ & $\begin{array}{l}-0.01 \\
(0.01)\end{array}$ & $\begin{array}{l}-0.01 \\
(0.03)\end{array}$ & $\begin{array}{l}-0.01 \\
(0.01)\end{array}$ \\
\hline Fragmentation index & $\begin{array}{c}0.44 \\
(0.45)\end{array}$ & $\begin{array}{l}-0.15 \\
(0.16)\end{array}$ & $\begin{array}{c}0.00 \\
(0.49)\end{array}$ & $\begin{array}{l}-0.19 \\
(0.14)\end{array}$ & $\begin{array}{l}-0.09 \\
(0.49)\end{array}$ & $\begin{array}{l}-0.18 \\
(0.15)\end{array}$ & $\begin{array}{l}-0.05 \\
(0.49)\end{array}$ & $\begin{array}{l}-0.15 \\
(0.16)\end{array}$ \\
\hline Pre-empted patents & & & $\begin{array}{c}0.11^{* * *} \\
(0.04)\end{array}$ & & $\begin{array}{c}0.11^{* * *} \\
(0.04)\end{array}$ & $\begin{array}{l}-0.00 \\
(0.01)\end{array}$ & $\begin{array}{l}0.11^{* *} \\
(0.04)\end{array}$ & $\begin{array}{l}-0.00 \\
(0.01)\end{array}$ \\
\hline Infringement & & & & $\begin{array}{c}0.07 * * * \\
(0.02)\end{array}$ & $\begin{array}{c}0.11^{* * *} \\
(0.03)\end{array}$ & $\begin{array}{c}0.07 * * * \\
(0.02)\end{array}$ & & \\
\hline Infringement (unprotected) & & & & & & & $\begin{array}{c}0.04 \\
(0.05)\end{array}$ & $\begin{array}{c}0.02 \\
(0.02)\end{array}$ \\
\hline Infringement (protected) & & & & & & & $\begin{array}{c}0.14 * * * \\
(0.04)\end{array}$ & $\begin{array}{c}0.07 * * * \\
(0.02)\end{array}$ \\
\hline $\begin{array}{l}\text { Reported figures are margi } \\
* * *(* *, *) \text { indicate a signi } \\
\text { Industry dummies are inclu }\end{array}$ & nut no & $\begin{array}{l}1 \% 0 \text { (5), } \\
\text { orted. }\end{array}$ & \%). & & & & & \\
\hline
\end{tabular}


Table 6: Marginal effects after probit regressions (cont.)

\begin{tabular}{|c|c|c|c|c|c|c|c|c|}
\hline & 9 & 10 & 11 & 12 & 13 & 14 & 15 & 16 \\
\hline & & & & & \multicolumn{2}{|c|}{ Discrete industries } & \multicolumn{2}{|c|}{ Complex industries } \\
\hline & $\begin{array}{c}\text { In- } \\
\text { licensing }\end{array}$ & $\begin{array}{l}\text { Cross- } \\
\text { licensing }\end{array}$ & $\begin{array}{c}\text { In- } \\
\text { licensing }\end{array}$ & $\begin{array}{l}\text { Cross- } \\
\text { licensing }\end{array}$ & $\begin{array}{c}\text { In- } \\
\text { licensing }\end{array}$ & $\begin{array}{l}\text { Cross- } \\
\text { licensing }\end{array}$ & $\begin{array}{c}\text { In- } \\
\text { licensing }\end{array}$ & $\begin{array}{c}\text { Cross- } \\
\text { licensing }\end{array}$ \\
\hline Log(employment) & $\begin{array}{c}0.04 * * * \\
(0.01)\end{array}$ & $\begin{array}{c}0.02^{* * *} \\
(0.00)\end{array}$ & $\begin{array}{c}0.05^{* * *} \\
(0.01)\end{array}$ & $\begin{array}{c}0.02 * * * \\
(0.00)\end{array}$ & $\begin{array}{l}0.04 * * \\
(0.01)\end{array}$ & $\begin{array}{l}0.01^{*} \\
(0.00)\end{array}$ & $\begin{array}{c}0.05^{* * *} \\
(0.01)\end{array}$ & $\begin{array}{c}0.02 * * * \\
(0.01)\end{array}$ \\
\hline R\&D/ employment & $\begin{array}{c}2.38 * * * \\
(0.70)\end{array}$ & $\begin{array}{c}0.36 * * \\
(0.16)\end{array}$ & $\begin{array}{c}2.51 * * * \\
(0.71)\end{array}$ & $\begin{array}{c}0.36 * * \\
(0.15)\end{array}$ & $\begin{array}{l}2.10 * * \\
(1.04)\end{array}$ & $\begin{array}{c}0.20 \\
(0.13)\end{array}$ & $\begin{array}{c}2.75^{* * *} \\
(0.98)\end{array}$ & $\begin{array}{c}0.41 \\
(0.28)\end{array}$ \\
\hline Patentstock/ employment & $\begin{array}{l}-0.06 \\
(0.22)\end{array}$ & $\begin{array}{l}0.13^{* *} \\
(0.05)\end{array}$ & $\begin{array}{c}0.03 \\
(0.21)\end{array}$ & $\begin{array}{c}0.14^{* * *} \\
(0.05)\end{array}$ & $\begin{array}{c}0.04 \\
(0.24)\end{array}$ & $\begin{array}{c}0.03 \\
(0.02)\end{array}$ & $\begin{array}{l}-0.27 \\
(0.49)\end{array}$ & $\begin{array}{c}0.26 \\
(0.17)\end{array}$ \\
\hline Export dummy & $\begin{array}{l}-0.04 \\
(0.04)\end{array}$ & $\begin{array}{l}0.00 \\
(0.01)\end{array}$ & $\begin{array}{l}-0.05 \\
(0.04)\end{array}$ & $\begin{array}{c}0.00 \\
(0.01)\end{array}$ & $\begin{array}{l}-0.00 \\
(0.06)\end{array}$ & $\begin{array}{l}-0.00 \\
(0.01)\end{array}$ & $\begin{array}{l}-0.09 \\
(0.07)\end{array}$ & $\begin{array}{l}-0.00 \\
(0.03)\end{array}$ \\
\hline Part of a group & $\begin{array}{c}0.04 \\
(0.03)\end{array}$ & $\begin{array}{c}0.01 \\
(0.01)\end{array}$ & $\begin{array}{c}0.04 \\
(0.03)\end{array}$ & $\begin{array}{c}0.01 \\
(0.01)\end{array}$ & $\begin{array}{c}0.04 \\
(0.04)\end{array}$ & $\begin{array}{c}0.00 \\
(0.01)\end{array}$ & $\begin{array}{c}0.04 \\
(0.04)\end{array}$ & $\begin{array}{c}0.01 \\
(0.02)\end{array}$ \\
\hline Collaboration B2B & $\begin{array}{c}0.03 \\
(0.04)\end{array}$ & $\begin{array}{c}0.00 \\
(0.01)\end{array}$ & $\begin{array}{c}0.03 \\
(0.04)\end{array}$ & $\begin{array}{c}0.00 \\
(0.01)\end{array}$ & $\begin{array}{c}0.07 \\
(0.05)\end{array}$ & $\begin{array}{c}0.01 \\
(0.00)\end{array}$ & $\begin{array}{l}-0.01 \\
(0.05)\end{array}$ & $\begin{array}{l}-0.00 \\
(0.02)\end{array}$ \\
\hline Collaboration B2C & $\begin{array}{c}0.12 * * * \\
(0.03)\end{array}$ & $\begin{array}{c}0.00 \\
(0.01)\end{array}$ & $\begin{array}{c}0.12^{* * *} \\
(0.03)\end{array}$ & $\begin{array}{c}0.00 \\
(0.01)\end{array}$ & $\begin{array}{c}0.17 * * * \\
(0.04)\end{array}$ & $\begin{array}{l}-0.00 \\
(0.00)\end{array}$ & $\begin{array}{c}0.05 \\
(0.05)\end{array}$ & $\begin{array}{c}0.02 \\
(0.02)\end{array}$ \\
\hline $\begin{array}{l}\text { Collaboration with } \\
\text { material suppliers }\end{array}$ & $\begin{array}{c}0.02 \\
(0.03)\end{array}$ & $\begin{array}{c}0.01 \\
(0.01)\end{array}$ & $\begin{array}{c}0.02 \\
(0.03)\end{array}$ & $\begin{array}{c}0.01 \\
(0.01)\end{array}$ & $\begin{array}{c}0.02 \\
(0.04)\end{array}$ & $\begin{array}{c}0.01 \\
(0.01)\end{array}$ & $\begin{array}{c}0.02 \\
(0.04)\end{array}$ & $\begin{array}{c}0.01 \\
(0.02)\end{array}$ \\
\hline $\begin{array}{l}\text { Collaboration with } \\
\text { service suppliers }\end{array}$ & $\begin{array}{c}0.00 \\
(0.03)\end{array}$ & $\begin{array}{c}0.01 \\
(0.01)\end{array}$ & $\begin{array}{c}0.00 \\
(0.03)\end{array}$ & $\begin{array}{c}0.01 \\
(0.01)\end{array}$ & $\begin{array}{c}0.01 \\
(0.04)\end{array}$ & $\begin{array}{l}-0.00 \\
(0.00)\end{array}$ & $\begin{array}{c}0.01 \\
(0.04)\end{array}$ & $\begin{array}{c}0.03 \\
(0.02)\end{array}$ \\
\hline $\begin{array}{l}\text { Collaboration with } \\
\text { competitors }\end{array}$ & $\begin{array}{c}0.04 \\
(0.03)\end{array}$ & $\begin{array}{l}0.02^{*} \\
(0.01)\end{array}$ & $\begin{array}{c}0.02 \\
(0.03)\end{array}$ & $\begin{array}{c}0.02 \\
(0.01)\end{array}$ & $\begin{array}{l}0.09^{*} \\
(0.05)\end{array}$ & $\begin{array}{c}0.01 \\
(0.01)\end{array}$ & $\begin{array}{l}-0.03 \\
(0.04)\end{array}$ & $\begin{array}{c}0.01 \\
(0.02)\end{array}$ \\
\hline $\begin{array}{l}\text { Collaboration with } \\
\text { universities }\end{array}$ & $\begin{array}{l}0.06^{* *} \\
(0.03)\end{array}$ & $\begin{array}{c}0.01 \\
(0.01)\end{array}$ & $\begin{array}{l}0.06 * * \\
(0.03)\end{array}$ & $\begin{array}{c}0.01 \\
(0.01)\end{array}$ & $\begin{array}{l}0.08^{* *} \\
(0.04)\end{array}$ & $\begin{array}{l}0.01^{*} \\
(0.01)\end{array}$ & $\begin{array}{c}0.06 \\
(0.04)\end{array}$ & $\begin{array}{l}-0.02 \\
(0.02)\end{array}$ \\
\hline East Germany & $\begin{array}{l}-0.01 \\
(0.03)\end{array}$ & $\begin{array}{l}-0.01 \\
(0.01)\end{array}$ & $\begin{array}{l}-0.01 \\
(0.03)\end{array}$ & $\begin{array}{l}-0.01 \\
(0.01)\end{array}$ & $\begin{array}{l}-0.03 \\
(0.04)\end{array}$ & $\begin{array}{l}0.00 \\
(0.01)\end{array}$ & $\begin{array}{l}0.00 \\
(0.04)\end{array}$ & $\begin{array}{l}-0.02 \\
(0.02)\end{array}$ \\
\hline Fragmentation index & $\begin{array}{c}0.85 \\
(0.60)\end{array}$ & $\begin{array}{c}0.04 \\
(0.18)\end{array}$ & $\begin{array}{c}0.04 \\
(0.59)\end{array}$ & $\begin{array}{l}-0.08 \\
(0.21)\end{array}$ & & & & \\
\hline Pre-empted patents & $\begin{array}{c}0.19 * * * \\
(0.05)\end{array}$ & $\begin{array}{c}0.01 \\
(0.02)\end{array}$ & $\begin{array}{c}0.11^{* * *} \\
(0.04)\end{array}$ & $\begin{array}{l}-0.00 \\
(0.01)\end{array}$ & $\begin{array}{l}0.11^{* *} \\
(0.06)\end{array}$ & $\begin{array}{c}0.00 \\
(0.01)\end{array}$ & $\begin{array}{l}0.11 * * \\
(0.06)\end{array}$ & $\begin{array}{l}-0.02 \\
(0.02)\end{array}$ \\
\hline Infringement & & & $\begin{array}{c}0.11^{* * *} \\
(0.04)\end{array}$ & $\begin{array}{c}0.08^{* * *} \\
(0.02)\end{array}$ & & & & \\
\hline $\begin{array}{l}\text { Infringement } \\
\text { (unprotected) }\end{array}$ & $\begin{array}{c}0.04 \\
(0.05)\end{array}$ & $\begin{array}{c}0.02 \\
(0.02)\end{array}$ & & & $\begin{array}{c}0.03 \\
(0.08)\end{array}$ & $\begin{array}{c}0.00 \\
(0.01)\end{array}$ & $\begin{array}{c}0.06 \\
(0.07)\end{array}$ & $\begin{array}{l}0.04 \\
(0.04)\end{array}$ \\
\hline Infringement (protected) & $\begin{array}{c}0.13^{* * *} \\
(0.04)\end{array}$ & $\begin{array}{c}0.07 * * * \\
(0.02)\end{array}$ & & & $\begin{array}{c}0.08 \\
(0.07)\end{array}$ & $\begin{array}{c}0.04 \\
(0.03)\end{array}$ & $\begin{array}{c}0.16^{* * *} \\
(0.06)\end{array}$ & $\begin{array}{l}0.07 * * \\
(0.03)\end{array}$ \\
\hline $\begin{array}{l}\text { Fragmentation * } \\
\text { pre-empted patents }\end{array}$ & $\begin{array}{c}-2.71^{* *} \\
(1.12)\end{array}$ & $\begin{array}{l}-0.58 \\
(0.38)\end{array}$ & & & & & & \\
\hline $\begin{array}{l}\text { Fragmentation * } \\
\text { infringement }\end{array}$ & & & $\begin{array}{l}-0.37 \\
(0.91)\end{array}$ & $\begin{array}{l}-0.16 \\
(0.27)\end{array}$ & & & & \\
\hline $\begin{array}{l}\text { Reported figures are mar } \\
* * *(* *, *) \text { indicate a sig } \\
\text { Industry dummies are inc }\end{array}$ & ed, but $n$ & $\begin{array}{l}\text { of } 1 \%(5 \% \\
\text { reported. }\end{array}$ & $\begin{array}{l}\text { rors in par } \\
\%, 10 \%) .\end{array}$ & theses. & & & & \\
\hline
\end{tabular}


Table 7: Bivariate probit models

\begin{tabular}{|c|c|c|c|c|c|c|c|c|}
\hline & \multicolumn{2}{|c|}{1} & \multicolumn{2}{|c|}{2} & \multicolumn{2}{|c|}{3} & \multicolumn{2}{|c|}{4} \\
\hline & $\begin{array}{c}\text { In- } \\
\text { licensing }\end{array}$ & $\begin{array}{c}\text { Cross- } \\
\text { licensing }\end{array}$ & $\begin{array}{c}\text { In- } \\
\text { licensing }\end{array}$ & $\begin{array}{c}\text { Cross- } \\
\text { licensing }\end{array}$ & $\begin{array}{c}\text { In- } \\
\text { licensing }\end{array}$ & $\begin{array}{c}\text { Cross- } \\
\text { licensing }\end{array}$ & $\begin{array}{c}\text { In- } \\
\text { licensing }\end{array}$ & $\begin{array}{c}\text { Cross- } \\
\text { licensing }\end{array}$ \\
\hline Log(employment) & $\begin{array}{c}0.20^{* * *} \\
(0.03)\end{array}$ & $\begin{array}{c}0.34^{* * *} \\
(0.05)\end{array}$ & $\begin{array}{c}0.18^{* * *} \\
(0.03)\end{array}$ & $\begin{array}{c}0.34^{* * *} \\
(0.05)\end{array}$ & $\begin{array}{c}0.16^{* * *} \\
(0.03)\end{array}$ & $\begin{array}{c}0.31^{* * *} \\
(0.05)\end{array}$ & $\begin{array}{c}0.15^{* * *} \\
(0.03)\end{array}$ & $\begin{array}{c}0.30 * * * \\
(0.05)\end{array}$ \\
\hline R\&D/ employment & $\begin{array}{c}8.14^{* * * *} \\
(2.26)\end{array}$ & $\begin{array}{c}6.14^{* *} \\
(2.56)\end{array}$ & $\begin{array}{c}8.26 * * * \\
(2.32)\end{array}$ & $\begin{array}{c}6.19 * * \\
(2.57)\end{array}$ & $\begin{array}{c}8.26^{* * * *} \\
(2.32)\end{array}$ & $\begin{array}{c}6.72 * * \\
(2.66)\end{array}$ & $\begin{array}{c}8.11^{* * *} \\
(2.31)\end{array}$ & $\begin{array}{c}6.42 * * \\
(2.64)\end{array}$ \\
\hline $\begin{array}{l}\text { Patentstock/ } \\
\text { employment }\end{array}$ & $\begin{array}{c}0.55 \\
(0.72)\end{array}$ & $\begin{array}{c}2.51^{* * * *} \\
(0.82)\end{array}$ & $\begin{array}{c}0.11 \\
(0.74)\end{array}$ & $\begin{array}{c}2.50^{* * * *} \\
(0.84)\end{array}$ & $\begin{array}{c}0.10 \\
(0.74)\end{array}$ & $\begin{array}{c}2.68^{* * *} \\
(0.85)\end{array}$ & $\begin{array}{c}0.10 \\
(0.75)\end{array}$ & $\begin{array}{c}2.50 * * * \\
(0.85)\end{array}$ \\
\hline Export dummy & $\begin{array}{l}-0.12 \\
(0.14)\end{array}$ & $\begin{array}{c}0.13 \\
(0.24)\end{array}$ & $\begin{array}{l}-0.14 \\
(0.14)\end{array}$ & $\begin{array}{c}0.13 \\
(0.24)\end{array}$ & $\begin{array}{l}-0.16 \\
(0.14)\end{array}$ & $\begin{array}{c}0.10 \\
(0.25)\end{array}$ & $\begin{array}{l}-0.16 \\
(0.14)\end{array}$ & $\begin{array}{c}0.07 \\
(0.25)\end{array}$ \\
\hline Part of a group & $\begin{array}{c}0.13 \\
(0.10)\end{array}$ & $\begin{array}{c}0.12 \\
(0.16)\end{array}$ & $\begin{array}{c}0.13 \\
(0.10)\end{array}$ & $\begin{array}{c}0.13 \\
(0.16)\end{array}$ & $\begin{array}{c}0.13 \\
(0.10)\end{array}$ & $\begin{array}{c}0.12 \\
(0.17)\end{array}$ & $\begin{array}{c}0.14 \\
(0.10)\end{array}$ & $\begin{array}{c}0.13 \\
(0.17)\end{array}$ \\
\hline Collaboration B2B & $\begin{array}{c}0.14 \\
(0.13)\end{array}$ & $\begin{array}{c}0.18 \\
(0.21)\end{array}$ & $\begin{array}{c}0.13 \\
(0.13)\end{array}$ & $\begin{array}{c}0.19 \\
(0.21)\end{array}$ & $\begin{array}{c}0.11 \\
(0.13)\end{array}$ & $\begin{array}{c}0.09 \\
(0.22)\end{array}$ & $\begin{array}{c}0.12 \\
(0.13)\end{array}$ & $\begin{array}{c}0.12 \\
(0.21)\end{array}$ \\
\hline Collaboration B2C & $\begin{array}{c}0.40^{* * *} \\
(0.10)\end{array}$ & $\begin{array}{c}0.03 \\
(0.16)\end{array}$ & $\begin{array}{c}0.39 * * * \\
(0.10)\end{array}$ & $\begin{array}{c}0.03 \\
(0.16)\end{array}$ & $\begin{array}{c}0.38^{* * * *} \\
(0.10)\end{array}$ & $\begin{array}{c}0.05 \\
(0.16)\end{array}$ & $\begin{array}{c}0.37 * * * \\
(0.10)\end{array}$ & $\begin{array}{c}0.01 \\
(0.16)\end{array}$ \\
\hline $\begin{array}{l}\text { Collaboration with } \\
\text { material suppliers }\end{array}$ & $\begin{array}{c}0.06 \\
(0.09)\end{array}$ & $\begin{array}{c}0.16 \\
(0.16)\end{array}$ & $\begin{array}{c}0.06 \\
(0.10)\end{array}$ & $\begin{array}{c}0.16 \\
(0.16)\end{array}$ & $\begin{array}{c}0.06 \\
(0.10)\end{array}$ & $\begin{array}{c}0.16 \\
(0.16)\end{array}$ & $\begin{array}{c}0.06 \\
(0.10)\end{array}$ & $\begin{array}{c}0.18 \\
(0.16)\end{array}$ \\
\hline $\begin{array}{l}\text { Collaboration with } \\
\text { service suppliers }\end{array}$ & $\begin{array}{c}0.04 \\
(0.09)\end{array}$ & $\begin{array}{l}0.20 \\
(0.14)\end{array}$ & $\begin{array}{l}0.03 \\
(0.09)\end{array}$ & $\begin{array}{c}0.21 \\
(0.14)\end{array}$ & $\begin{array}{c}0.02 \\
(0.09)\end{array}$ & $\begin{array}{c}0.18 \\
(0.15)\end{array}$ & $\begin{array}{c}0.01 \\
(0.09)\end{array}$ & $\begin{array}{c}0.17 \\
(0.14)\end{array}$ \\
\hline $\begin{array}{l}\text { Collaboration with } \\
\text { competitors }\end{array}$ & $\begin{array}{c}0.07 \\
(0.10)\end{array}$ & $\begin{array}{c}0.18 \\
(0.16)\end{array}$ & $\begin{array}{c}0.08 \\
(0.10)\end{array}$ & $\begin{array}{c}0.18 \\
(0.16)\end{array}$ & $\begin{array}{c}0.09 \\
(0.10)\end{array}$ & $\begin{array}{c}0.21 \\
(0.16)\end{array}$ & $\begin{array}{c}0.11 \\
(0.10)\end{array}$ & $\begin{array}{l}0.28^{*} \\
(0.16)\end{array}$ \\
\hline $\begin{array}{l}\text { Collaboration with } \\
\text { universities }\end{array}$ & $\begin{array}{c}0.26^{* * *} \\
(0.09)\end{array}$ & $\begin{array}{c}0.23 \\
(0.15)\end{array}$ & $\begin{array}{c}0.25^{* * * *} \\
(0.09)\end{array}$ & $\begin{array}{c}0.23 \\
(0.15)\end{array}$ & $\begin{array}{l}0.22 * * \\
(0.09)\end{array}$ & $\begin{array}{c}0.15 \\
(0.16)\end{array}$ & $\begin{array}{l}0.24^{* *} \\
(0.09)\end{array}$ & $\begin{array}{c}0.20 \\
(0.16)\end{array}$ \\
\hline East Germany & $\begin{array}{l}-0.10 \\
(0.10)\end{array}$ & $\begin{array}{l}-0.23 \\
(0.20)\end{array}$ & $\begin{array}{l}-0.08 \\
(0.11)\end{array}$ & $\begin{array}{l}-0.24 \\
(0.20)\end{array}$ & $\begin{array}{l}-0.04 \\
(0.11)\end{array}$ & $\begin{array}{l}-0.11 \\
(0.21)\end{array}$ & $\begin{array}{l}-0.05 \\
(0.11)\end{array}$ & $\begin{array}{l}-0.16 \\
(0.20)\end{array}$ \\
\hline Fragmentation index & $\begin{array}{c}1.49 \\
(1.54)\end{array}$ & $\begin{array}{l}-2.64 \\
(2.46)\end{array}$ & $\begin{array}{c}0.01 \\
(1.65)\end{array}$ & $\begin{array}{l}-2.60 \\
(2.56)\end{array}$ & $\begin{array}{l}-0.30 \\
(1.66)\end{array}$ & $\begin{array}{l}-3.81 \\
(2.72)\end{array}$ & $\begin{array}{l}-0.15 \\
(1.66)\end{array}$ & $\begin{array}{l}-2.83 \\
(2.65)\end{array}$ \\
\hline Pre-empted patents & & & $\begin{array}{c}0.37 * * * \\
(0.14)\end{array}$ & $\begin{array}{l}-0.02 \\
(0.21)\end{array}$ & $\begin{array}{c}0.37 * * * \\
(0.14)\end{array}$ & $\begin{array}{c}-0.06 \\
(0.22)\end{array}$ & $\begin{array}{c}0.36 * * \\
(0.14)\end{array}$ & $\begin{array}{l}-0.07 \\
(0.22)\end{array}$ \\
\hline Infringement & & & & & $\begin{array}{c}0.33^{* * *} \\
(0.10)\end{array}$ & $\begin{array}{c}0.86^{* * *} \\
(0.15)\end{array}$ & & \\
\hline $\begin{array}{l}\text { Infringement } \\
\text { (unprotected) }\end{array}$ & & & & & & & $\begin{array}{c}0.13 \\
(0.16)\end{array}$ & $\begin{array}{c}0.22 \\
(0.24)\end{array}$ \\
\hline Infringement (protected) & & & & & & & $\begin{array}{c}0.42^{* * *} \\
(0.12)\end{array}$ & $\begin{array}{c}0.76^{* * *} \\
(0.16)\end{array}$ \\
\hline Constant & $\begin{array}{c}-2.35 * * * \\
(0.27)\end{array}$ & $\begin{array}{c}-4.26 * * * \\
(0.48)\end{array}$ & $\begin{array}{c}-2.24 * * * \\
(0.28)\end{array}$ & $\begin{array}{c}-4.29 * * * \\
(0.49)\end{array}$ & $\begin{array}{c}-2.23 * * * \\
(0.28)\end{array}$ & $\begin{array}{c}-4.33 * * * \\
(0.51)\end{array}$ & $\begin{array}{c}-2.18 * * * \\
(0.28)\end{array}$ & $\begin{array}{c}-4.17 * * * \\
(0.50)\end{array}$ \\
\hline rho & $\begin{array}{r}0.43 \\
(0 .\end{array}$ & $\begin{array}{l}* * * \\
09)\end{array}$ & $\begin{array}{r}0.4 \\
(0\end{array}$ & *** & $\begin{array}{r}0.4 \\
(0 .\end{array}$ & $\begin{array}{l}* * * \\
10)\end{array}$ & $\begin{array}{r}0.4 \\
(0 .\end{array}$ & $\begin{array}{l}* * * \\
10)\end{array}$ \\
\hline $\begin{array}{l}\mathrm{N} \\
\mathrm{ll}\end{array}$ & $\begin{array}{r}11 \\
-76 \\
\end{array}$ & $\begin{array}{l}62 \\
3.47\end{array}$ & $\begin{array}{r}1 \\
-75 \\
\end{array}$ & & $\begin{array}{r}11 \\
-74\end{array}$ & $\begin{array}{l}62 \\
.61\end{array}$ & $\begin{array}{r}11 \\
-74\end{array}$ & $\begin{array}{l}62 \\
5.52\end{array}$ \\
\hline $\begin{array}{l}\text { Reported figures are coe } \\
* * *(* *, *) \text { indicate a sig } \\
\text { Industry dummies are in }\end{array}$ & $\begin{array}{l}\text { ients; stan } \\
\text { icance lev } \\
\text { ded, but n }\end{array}$ & $\begin{array}{l}\text { dard errors } \\
\text { l of } 1 \%(5 \\
\text { t reported }\end{array}$ & $\begin{array}{l}\text { parenthe } \\
10 \%) .\end{array}$ & & & & & \\
\hline
\end{tabular}

